\title{
The soil fungal community of native woodland in Andean Patagonian forest: A case study considering experimental forest management and seasonal effects
}

\author{
Ayelen Inés Carron ${ }^{\mathrm{a}, \mathrm{b}, *}$, Lucas Alejandro Garibaldi ${ }^{\mathrm{c}}$, Sebastian Marquez ${ }^{\mathrm{d}}$, Sonia Fontenla ${ }^{\mathrm{a}, \mathrm{b}}$ \\ ${ }^{a}$ Laboratorio de Microbiología Aplicada y Biotecnología Vegetal y del Suelo, Centro Regional Universitario Bariloche, Universidad Nacional del Comahue (UNComahue), \\ Argentina \\ ${ }^{\mathrm{b}}$ Instituto Andino Patagónico de Tecnologías Biológicas y Geoambientales (IPATEC) UNComahue - Consejo Nacional de Investigaciones Científicas y Técnicas (CONICET), \\ Argentina \\ ${ }^{\mathrm{c}}$ Instituto de Investigaciones en Recursos Naturales, Agroecología y Desarrollo Rural (IRNAD), Sede Andina, Universidad Nacional de Río Negro (UNRN) and CONICET, \\ Argentina \\ d Instituto de Investigación en Biodiversidad y Medio Ambiente (INIBIOMA) UNComahue - Consejo Nacional de Investigaciones Científicas y Técnicas (CONICET), \\ Argentina
}

\section{A R T I C L E I N F O}

\section{Keywords:}

Soil fungal classification

Diversity analysis

Shrubland management

Harvesting

Implantation

Intra-annual effects

Soil characteristics

\begin{abstract}
A B S T R A C T
Forest management can alter soil fungal communities which are important in the regulation of biogeochemical cycles and other ecosystem services. The current challenge of sustainable management is that management be carried out while preserving the bioecological aspects of ecosystems. Mixed Patagonian woodlands are subject to continuous disturbance (fire, wood extraction, and livestock), with unknown consequences for soil fungal communities. Our objective was to study the fungal community and the effects of an experimental forest management program, which combines harvesting and implantation, on the soil fungal communities in Patagonian woodland, in Argentina; considering contrasting seasons and soil parameters. At site level, the mixed woodlands appear to have greater soil cover with AM plants and soil chemical characteristics similar to other forest environments in the same region, with an intermediate fungal diversity value. When the seasonal effect was analyzed, no changes were observed in the fungal richness and diversity index, whereas modifications were recorded in the class level, in the ecological guilds, and in certain soil parameters; the inversion of phyla should be highlighted. Ascomycota and Basidiomycota were the predominant phyla, and presented a tendency to an inversion between seasons: Ascomycota fungi predominated in autumn, while Basidiomycota were more abundant in summer. The Glomeromycota were not well represented in this study. The most abundant classes were Agaricomycetes, followed by Leotiomycetes, Sordariomycetes, and Tremellomycetes, with some changes in the proportions between the two seasons, which could be related to certain soil characteristics. The most abundant orders in both seasons were Agaricales, Helotiales, Mortierellales, and Filobasidiales, correlated with some soil characteristics. The ordination analysis (NMDS) showed a correlation between taxonomic assignation and some soil characteristics, and only between class seasons. The most abundant ecological guild was saprotrophs (in both seasons: Hygrocybe, Mortierella, Cryptococcus), followed by plant pathogens (Ilyonectria, which increase in autumn); and the ectomycorrhizal symbiont (Hygrocybe in both seasons, while in summer Cortinarius, Clitopilus, and Geoglossum), all are related to C and N cycle. The only post-management changes observed in soil fungal community and chemical characteristics were in fungal richness (OTUs) and available phosphorus values; all the others (diversity indexes, taxonomy, and ecological guilds) were unaffected by this anthropic disturbance. It should be highlighted that available $\mathrm{P}$ and fungal species richness could be proposed as bioindicators. Future studies in native management programs, considering other aspects such as diversity of vegetation uses and system functions of the area will allow us to assess whether some of these changes are early bio-indicators of sustainable use and management.
\end{abstract}

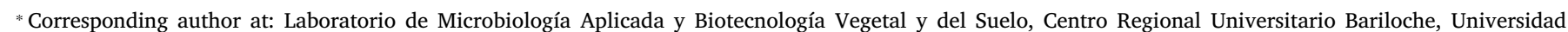
Nacional del Comahue (UNComahue), Argentina.

E-mail address: ayecarron@comahue-conicet.gob.ar (A.I. Carron). 


\section{Introduction}

In the twenty-first century, sustainable forest management is a principle that ensures the production of goods and services from forest ecosystems in an optimal, permanent manner; it constitutes a strategy for natural resource management that considers forestry activities in ecological, economic and social contexts (Aguirre-Calderón, 2015). Forest management modifies the original composition of forests through changes in the vegetation composition of tree species, the structure of age classes and the proportions of biomass contributed to the soil. It also influences diverse components of the ecosystem, directly and indirectly, including the availability and quality of resources for microbial development, which leads to alterations in the structure and succession of the microbial community (Goldmann et al., 2015; Purahong et al., 2015). The challenge of sustainable forest management and the basis of the new paradigms is responsible stewardship of the forests and forest lands; that is, regulation of their use in such a way as to preserve their biological diversity, productivity, capacity for regeneration, vitality, and ability to fulfil their ecological, economic and social functions, without causing damage to other ecosystems (Grossberg, 2009; Higman et al., 2000; Malmsheimer et al., 2008).

Despite new and more efficient approaches to biodiversity, there are still considerable gaps in geographical data in soil biodiversity (Tedersoo et al., 2014; Bueno et al., 2017; Cameron et al., 2018). South America holds one of the most diverse biodiversity hotspots, but little research has been carried out in the region, particularly on belowground fundamental organisms and mycorrhizal symbiosis (Pagano and Lugo, 2019).

The Fungi kingdom is one of the most diverse Eukaryote lineages and is estimated to contain several million species (2.2-3.8 million species; Hawksworth and Lücking, 2017). Fungi are important saprophytic, symbiotic and pathogenic organisms that play critical roles in the function of terrestrial and aquatic ecosystems (Read and PerezMoreno, 2003; Van Der Heijden et al., 2008; Taylor and Sinsabaugh, 2015; Grossart et al., 2016). Soil fungal communities represent the highest soil biomass and are essential for the maintenance of a large number of ecosystem services (diversity, abundance and plant productivity, soil health, water quality, biocontrol of pathogens, among others). Mycorrhizal (Brundrett, 2004) and free-living rhizospheric fungi (Raaijmakers et al., 2009) are associated with plant species, and they take part in nutrient fluxes from soil to plants (Van der Heijden et al., 2015). Symbiotic mycorrhizal fungi, such as arbuscular mycorrhizal (AM) fungi or ectomycorrhizal fungi (ECM), are ubiquitous components of most ecosystems throughout the world, and constitute a key component of soil microbiota (Van der Heijden et al., 1998, Brundrett and Tedersoo, 2018; Pagano and Lugo, 2019): they mobilize and transport nutrients, especially carbon (C), nitrogen (N), and phosphorus (P), and they also reduce water stress (Augé, 2001) and improve soil aggregation in eroded soils (Caravaca et al., 2002).

Environmental conditions have been shown to play an important role in determining the soil fungal community. Diverse biotic and abiotic factors could affect the structure and function of these communities, such as host-plant diversity (Tedersoo et al., 2013; Bonito et al., 2014), seasonal patterns (Berg et al., 1998; Mandyam and Jumpponen, 2005; Zinger et al., 2009; Dumbrell et al., 2011), weather and geographic factors (Talbot et al., 2013; Miyamoto et al., 2015; Truong et al., 2019), and edaphic variables (Zinger et al., 2009; Dumbrell et al., 2011; Kauserud et al., 2011; Davey, 2012; Peay et al., 2015; Erlandson et al., 2016). Changes in land use, such as forest management, can modify the fungal soil community and alter the balance between carbon (C) allocation to ECM fungi, and N and P acquisition by ECM plants, thereby influencing global $\mathrm{C}$ storage and N/P cycles in forest ecosystems (Baskaran et al., 2017; Corrales et al., 2017). Forest harvesting affects ECM fungi by changing the age structure and species composition of their host plants, and by modifying the physical, chemical and biological components of their soil habitat. Some ECM fungi taxa appear to be primarily associated with mature forests, while others may persist as resistant soil propagules until disturbances occur such as fire or harvesting, providing an opportunity for colonization of seedling roots (Taylor et al., 2000; Jones et al., 2002, 2003). Management without extraction of residual trees plays a role in recently harvested forests by retaining a unique ECM fungal community, by influencing species composition and enhancing the diversity of ECM fungal communities on seedlings adjacent to trees (Cline et al., 2005). Another point of view was presented by Lauber et al. (2008) when considering the effects of forest management on soil fungal communities in boreal forests, suggesting that fungal community composition is more closely associated with changes in soil nutrient content than with different land uses.

In Argentina nowadays the sustainable management of native environments is regulated by National legislation (Law 26.331) and Provincial laws. These laws establish the need to implement sustainable wood extraction management (harvesting), and to encourage environmental restoration action such as the implantation of native plants in extraction areas. Andean Patagonian forests occupy an area of 3 million hectares, representing approximately $10 \%$ of the total forest area of Argentina (Laclau, 1997; Donoso and Lara, 1995; SAyDS, 2007). In these forests one of the principal dominant tree species is Nothofagus spp. (Cabrera, 1976; SAyDS, 2007). The mixed woodlands of this region are dominated by young arboreal plants and shrub species. From the XIX century the Northwestern Patagonian region has suffered a drastic reduction in vegetation cover due to indiscriminate burning and deforestation caused by settlements in the region (Kitzberger and Veblen, 1999). This kind of disturbance has significantly affected its conservation status (Donoso and Lara, 1995) and the ecological functions of these forests. The mixed woodlands (also called shrublands) are a common successional post-fire environment included in these forests, which are dominated by young arboreal plants, mainly the ECM $N$. antarctica and some AM tree and shrub species. The mixed woodlands have been subject to anthropic disturbance (Kitzberger and Veblen, 1999) due to their high productive capacity for livestock rearing (sheep and cattle) and wood products (poles and firewood) used in domestic heating and for sale on the timber market. It is estimated that more than $70 \%$ of mixed woodland in the Patagonian region is under some kind of forest management (Peri et al., 2005), with different intensities and extraction objectives (Veblen et al., 1992; Peri et al., 2005). Most of these woodlands lack a sustainable management program, causing a negative impact on the ecosystem and jeopardizing the sustainability of the system (Peri et al., 2005). A suitable management program is thus required for these native forest ecosystems (Tacón Clavaín, 2004).

Authors such as Peri et al. (2005) and Reque et al. (2007) have worked in forests where $N$. antarctica predominates, and have characterized and proposed sustainable management guidelines for these ecosystems. However, data concerning the effects of different management practices on these native forests is limited, and almost no information is available regarding their effect on soil microorganism communities. In the Northwest Patagonian forest (including woodlands) some authors (La Manna and Barroetaveña, 2011; Berrios et al., 2014) indicated that the soil under $N$. antarctica presented higher $N$ content than under other shrubs, and they suggested that uncontrolled productive use or the replacement of this native species could reduce the $\mathrm{N}$ content of the soil with possible negative consequences for the environment. However, knowledge is lacking on the effects of different management practices on this extensively-used woodland. Furthermore, almost no information is available regarding forest management effects on the soil microorganism communities.

Our objective was to study the fungal community and the effects of an experimental forest management program, which combines harvesting and implantation, on these communities in an Argentinian Patagonian mixed woodland. The study was carried out at one year of installation, in two contrasting seasons, and soil chemical characteristics were considered. 


\section{Materials and methods}

\subsection{Study area and sampling site}

This work was carried out in a site called El Foyel $\left(41^{\circ} 38^{\prime} 48.44^{\prime \prime} \mathrm{S}\right.$, $71^{\circ} 29^{\prime} 59.06^{\prime \prime} \mathrm{W}$ ), a representative area of native mixed woodland located in the homonymous community (Río Negro Province, Argentina), in Northwest Patagonia, Argentina. This site has a slope and an average altitude of $850 \mathrm{~m}$ above sea level. It is a mixed high woodland, mainly covered by low trees of Embotrium coccineum, Austrocedrus chilensis, Lomatia hirsuta, Maytenus sp., and N. antarctica, and by mixed shrubs such as Berberis sp., Discarya chacaye, Diostea juncea, and Schinus patagonicus. Phytogeographically, the site is located in the Subantarctic Domain, Andean-Patagonian region, Subantarctic Province, and the deciduous forest district (Cabrera, 1971). Average rainfall is $1100 \mathrm{~mm}$ annually, occurring principally during autumn and winter, due to the humid winds of the Pacific. Winter precipitation is mainly in the form of snow. Summer is the driest season. The climate in the area is temperate cold, with an average annual maximum temperature of $17^{\circ} \mathrm{C}$; the minimum temperature is $2.5^{\circ} \mathrm{C}$, and the annual average is $8.4{ }^{\circ} \mathrm{C}$.

On the El Foyel site the Universidad Nacional de Río Negro group (led by Dr. L. Garibaldi) established a $11340 \mathrm{~m}^{2}$ experimental program consisting of eight plots (each $31.5 \times 45 \mathrm{~m}$ ) which simultaneously underwent an experimental forest management program that combined harvesting and implantation factors (Table 1). The eight plots were located consecutively in the site (numbered from 1 to 8 , Table 1) and each was submitted to a certain level of harvesting (four levels), and one implantation condition [two levels: implanted (I) with native forest species of ecological interest, and non-implanted (NI)]. Table 1 shows that each harvesting treatment had two plots, one with implanted native species and the other without implanted species.

Harvesting was performed as follows: three intensities were installed (with $0.3,0.5$ and 0.7 of the basal area removed, corresponding to 30, 50 , and $70 \%$ respectively), and a control plot that was not harvested $(0 \%$, Table 1$)$. In each plot harvesting was carried out in six transects of different widths, according to the harvesting intensity. In plots with 0.3 harvesting intensity, six transects of $1.5 \mathrm{~m}$ width were cut; in plots with 0.5 harvesting six transects $2.5 \mathrm{~m}$ wide were cut, and for plots with 0.7 harvesting the transects cut were $3.5 \mathrm{~m}$ wide. Within transects the vegetation was cut at ground level (except for A. chilensis trees, which were not cut). In each plot all the larger firewood was extracted, while the smaller plant material was left scattered on the harvesting intensity strip as soil cover.

Implantation: six native species of high forest value were planted: $A$. chilensis, which are colonized by AM, and five ECM Nothofagus species ( $N$. antartica, $N$. dombeyi, $N$. nervosa, $N$. obliqua, and $N$. pumilio) (Fontenla et al., 1998; Diehl et al., 2003, 2008). The seedlings used were between four and six years old at the time of planting. They came from three different geographical origins and were cultivated in greenhouses in the region. Each species was planted in equal quantities, 30 plants per plot, resulting in a planting density of approximately 1269 plants ha ${ }^{-1}$, per species.

For the intra-annual seasonality analysis, sampling was carried out in autumn (May of 2014) and summer (January of 2015), one year after the forest management treatment had been established (May of 2013).

Table 1

Experimental block assay detailing the distribution of plots according to the forest management established: harvesting (4 levels) and implanted (I) with native forest species or non-implanted (NI).

\begin{tabular}{lllllllll}
\hline Plot number & 1 & 2 & 3 & 4 & 5 & 6 & 7 & 8 \\
\hline Harvesting & 0.3 & 0.7 & 0 & 0.5 & 0.7 & 0.3 & 0 & 0.5 \\
Implantation & NI & I & NI & I & NI & I & I & NI \\
\hline
\end{tabular}

${ }^{1}$ Harvesting intensity expressed as basal area removed.
One soil sample was collected per plot, composed of 25 equidistantly distributed sub-samples, thus forming a total of eight samples per season. The "pooling" of these 25 samples enabled us to properly estimate the average value of each plot, but did not allow analysis of within-plot variability, which can be important in fungal communities. The samples were stored at $4{ }^{\circ} \mathrm{C}$ for one day. Under aseptic conditions in the laboratory each sample was homogenized and fractionated for the different determinations: gravimetric humidity, soil chemical analyses, and DNA extraction and amplification.

\subsection{Description of plot vegetation and mycorrhizal behavior}

Before establishment of the experimental program, M. Goldemberg (per.com.) described some particular characteristics of the experimental site where the plot was established; he determined the percentage cover of dead organic matter (leaf litter, detritus and branches), bare soil and abundant plant species. Using bibliographical data on the region (Fernández et al., 2012; Fontenla et al., 1998, 2001), each plant species used for determination of cover was theoretically assigned a mycorrhizal behavior. Both types of result, cover and mycorrhizal behavior of the species were analyzed together.

\subsection{Soil characteristics}

Chemical characteristics were determined in a soil sample from each plot, in both seasons. Percentage of gravimetric humidity was determined from the fresh samples (three repeats per sample) after drying at $105^{\circ} \mathrm{C}$ until constant weight ( $48 \mathrm{~h}$ approx.). The $\mathrm{pH}$ in deionized water (2:5 w:v) and conductivity (EC $=1: 5 \mathrm{w}: \mathrm{v}-\mu \mathrm{cimen} \mathrm{cm}^{-1}$ ) were measured (at room temperature) from dry soil samples sieved through a $2 \mathrm{~mm}$ sieve, using a pH-meter and an electric conductivity meter, respectively. The remaining determinations were made with dried soil samples at room temperature $\left(20-25^{\circ} \mathrm{C}\right)$ sieved through a $0.5 \mathrm{~mm}$ sieve. Percentages of total carbon $(\mathrm{C})$ and total nitrogen (N) were determined by combustion at $900{ }^{\circ} \mathrm{C}$ (Nelson and Sommers, 1996) using the NC Soil analyzer Flash EA 1112 carbon-nitrogen analyzer (Thermo Fisher Scientific, USA). Available phosphorus (Olsen P - $\mu \mathrm{g}$ $\mathrm{g}^{-1}$ ) was determined by extraction with a $0.5 \mathrm{~N} \mathrm{NaHCO}_{3}$ solution and quantified by colorimetry with ascorbic acid, according to Kuos (1996). Percentage Calcium (Ca) was determined by extraction with $1 \mathrm{~N}$ ammonium acetate, followed by atomic absorption (Suarez, 1996) using AAnalyst 100 (Perkin-Elmer, USA). Plots 3 and 7 were not analyzed in autumn.

\subsection{Molecular and bioinformatic analysis}

The fungal internal transcribed spacer (ITS) region was sequenced for each soil sample. The ITS fungal region was amplified by genomic soil DNA, using a PowerSoil DNA isolation Kit (Mo Bio Laboratories, USA), following the manufacturer's instructions. DNA concentration was quantified on a QuantiT ${ }^{\mathrm{TM}}$ PicoGreen ${ }^{\circledR}$ dsDNA Assay Kit (Invitrogen, USA). Genomic DNA was used as a template for PCR amplification of the ITS ribosomal region using primers: ITS1F (5'- CTTGGTCATTTAG AGGAACTAA-3'; Gardes and Bruns, 1996) and ITS4 (5'- TCCTCCGCT TATTGATATGC-3'; White et al., 1990) with TAG extensions. Each PCR

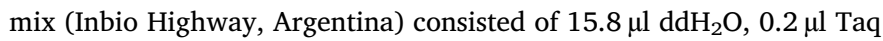
polymerase, $2.5 \mu \mathrm{l} 10 \mathrm{x}$ PCR buffer, $2 \mu \mathrm{lgCl}_{2}(25 \mathrm{mM}), 0.5 \mu \mathrm{l}$ dNTP mixture $(2 \mathrm{mM}), 0.5 \mu \mathrm{l}$ of each primer $(10 \mu \mathrm{M}), 1 \mu \mathrm{lBS}\left(20 \mathrm{mg} \mathrm{ml}^{-1}\right.$; Sigma, USA) and $2 \mu$ of a diluted DNA template. The parameters of the first PCR were as follows: an initial denaturation step at $95^{\circ} \mathrm{C}$ for $5 \mathrm{~min}$ was followed by 35 cycles consisting of denaturation at $95^{\circ} \mathrm{C}$ for $30 \mathrm{~s}$, annealing at $55^{\circ} \mathrm{C}$ for $30 \mathrm{~s}$ and extension at $72{ }^{\circ} \mathrm{C}$ for $60 \mathrm{~s}$, followed by the final extension at $72{ }^{\circ} \mathrm{C}$ for $10 \mathrm{~min}$. A second amplification of the PCR products was performed to include sequencing adapters and barcodes to identify each of the samples (Manual FLX + Roche, jun 2013, Instituto de Agrobiotecnología Rosario, INDEAR, Rosario, Argentina). 
The amplicon libraries were then purified with Agencourt AMPure XP according to the Amplicon Library Preparation Method Manual - GS FLX Titanium Series (Roche, USA). Purified amplicons were quantified using the Quant-iT ${ }^{\mathrm{rm}}$ PicoGreen ${ }^{\circledR}$ dsDNA Assay Kit (Invitrogen, USA). The amplicon pool was prepared with all the equimolar libraries, according to the corresponding concentration ( $\mathrm{ng} \mathrm{ul}^{-1}$ ). This pool was brought to work concentration (1e7 molecules $\mathrm{ul}^{-1}$ ). Sequencing was performed with the FLX + Roche Sequencing platform (INDEAR 2015).

The sequences were quality-filtered and pooled using Qiime v. 1.3.0 (Caporaso et al., 2010). The filtration criteria were: ambiguous bases that exceeded 6 bases, with an average quality score below the minimum of 25; homopolymer maximum exceeding 6 bases; inequalities in the primer exceeding 10 bases; and absence of a discernible reverse primer. The aligner was made using the MUSCLE v38 method (Edgar, 2004). OTU mapping was done with Uclust v1.2.22 (Caporaso et al., 2010) parameters at $97 \%$ similarity. OTUs represented by a single sequence were discarded from the data set, according to Tedersoo et al. (2010). The number of raw input sequences was 119235, giving a total of 55,345 sequences at the end of the process.

\subsection{Fungal community analysis}

Diversity analyses: these were carried out using indices: OTU richness, expected richness (Chao1), evenness as equitability ( $=1-\mathrm{D}$, where $\mathrm{D}$ is Simpson diversity index), community diversity (Shannon-Weaver index, H), and similarity between communities (Bray-Curtis). The diversity indices were calculated using the vegan 2.5-6 (Oksanen et al., 2019) and fossil 0.3.0 packages for expected richness (Vavrek, 2011), in R 3.3.1 (R Core Team, 2019). Estimated species richness was also calculated with rarefaction curves using the OTU numbers, and curves were drawn using the vegan package rarefy function (Oksanen et al., 2019). This was carried out for the entire data set $(n=16$ samples) and for each season: autumn (A) and summer (S) ( $n=8$ samples/season).

Taxonomic fungal classification: the OTUs were classified carrying out the RAPD classifier application (Manual FLX + Roche, jun 2013, Instituto de Agrobiotecnología Rosario, INDEAR, Rosario, Argentina), with a confidence of 0.5 (Wang et al., 2007), using the UNITE 12_11 ITS database. Fungal taxonomy was considered at different levels: the abundance of phyla, classes, orders, genera, and species. For each plot, the number of sequences for each taxon was standardized by rarefaction using the vegan package rarefy function (Oksanen et al., 2019).

Ecological guilds: OTUs were assigned an ecological guild using FUNGuild database (Nguyen et al., 2016). As the authors suggest, we filtered the assignments according to their confidence ranking ("highly probable", "probable", and "possible"; reflecting the likelihood that a taxon belongs to a given guild). Only assignments with highly probable and probable confidence were considered, and the number of sequences for each guild was standardized by rarefaction. The arbuscular mycorrhizal fungi were not analyzed since the primers used cannot identify the community of Glomeromycetes well (Stockinger et al., 2010; Schoch et al., 2012).

\subsection{Statistical analysis}

To evaluate forest management (harvesting and implantation factors), seasonal effects, soil chemical characteristics (humidity, $\mathrm{pH}$, conductivity, $\mathrm{C}, \mathrm{N}, \mathrm{P}$, and $\mathrm{Ca}$ ) and fungal community diversity (observed and expected richness, Simpson equitability index, Shannon Weaver diversity index) were estimated using general mixed-effect models. Fixed effects included harvesting intensity (quantitative variable modeled with a second order polynomial function), implantation (I vs. NI), season (autumn vs. summer), and their two-way interactions. The hierarchical data structure (two measures in each plot over time) was accounted for by including plot as a random effect. In particular, our model estimated different intercepts for each plot. A different model was estimated for each soil and fungal community characteristic as a response variable, and normal distribution was assumed for all models. Model assumptions were met in all cases, and homogeneity of variances and normality were evaluated with residual and predicted graphs, Q-Q plots, and Shapiro-Wilk tests. We used the corrected Akaike Information Criterion (AICc) to select the model that best described the behavior of the fungal community with respect to management and season variables. The AICc values and estimation of the parameters for the final models were obtained from the maximum likelihood estimates (Zuur et al., 2009).

Structure of the fungal community: In order to represent the structure of the fungal communities at plot level, we performed a nonmetric multidimensional scaling analysis (NMDS). The abundance of phyla, classes, orders, and ecological guilds (rarefied) was considered in correlation with forest management, season, and soil characteristics. The parameters used were the Bray-Curtis dissimilarity, with 999 free permutations. The variables that had a significant effect on the ordering of the fungal communities were plotted using envfit function, and were also evaluated with distance-based RDA.

All statistical analyses were performed using the vegan 2.5-6 (Oksanen et al., 2019), nlme 3.1-140 (Pinheiro et al., 2019) and MuMIn 1.43.6 (Barton, 2019) packages in R (R Core Team, 2019).

\section{Results}

\subsection{Vegetation and soil characteristics}

The El Foyel site is a high woodland (as previously mentioned); however, Goldemberg (per.com.) reported that in this area the experimental program plots had certain particular vegetation characteristics: the soil was covered by a significant amount of dead organic matter (leaf litter, detritus and branches) over $75 \%$ in all the plots and the percentages of bare soil were between 0 and $9.5 \%$, the highest value

Table 2

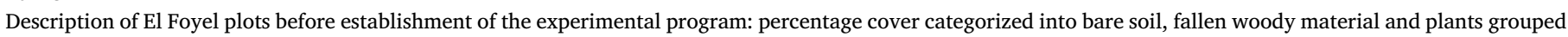
by their mycorrhizal types.

\begin{tabular}{|c|c|c|c|c|c|c|c|c|}
\hline Cover $(\%) /$ Plot & $\begin{array}{l}1 \\
\left(0.3^{1} \mathrm{NI}\right)\end{array}$ & $\begin{array}{l}2 \\
(0.7 \text { I) }\end{array}$ & $\begin{array}{l}3 \\
(0 \mathrm{NI})\end{array}$ & $\begin{array}{l}4 \\
(0.5 \mathrm{I})\end{array}$ & $\begin{array}{l}5 \\
(0.7 \mathrm{NI})\end{array}$ & $\begin{array}{l}6 \\
(0.3 \mathrm{I})\end{array}$ & $\begin{array}{l}7 \\
(0.0 \mathrm{I})\end{array}$ & $\begin{array}{l}8 \\
(0.5 \mathrm{NI})\end{array}$ \\
\hline Bare soil & 9.5 & 0.0 & 0.0 & 2.0 & 0.0 & 3.3 & 0.5 & 2.0 \\
\hline Leaf litter, branches and plant detritus & 88.8 & 76.3 & 98.8 & 100.0 & 98.0 & 97.5 & 100.0 & 98.8 \\
\hline AM plants & 98.8 & 30.5 & 19.5 & 14.0 & 25.0 & 18.8 & 17.5 & 51.0 \\
\hline ECM Nothofagus antartica & 1.3 & 0.0 & 0.8 & 0.0 & 0.0 & 0.0 & 0.0 & 0.0 \\
\hline MER Gaultheria mucronata & 0.0 & 0.0 & 0.0 & 0.5 & 3.0 & 0.0 & 0.0 & 0.0 \\
\hline ND mycorrhizal species & 0.0 & 0.0 & 1.0 & 0.0 & 3.5 & 3.0 & 0.0 & 0.0 \\
\hline NH Embothrium coccineum & 0.0 & 6.0 & 1.5 & 7.3 & 2.8 & 6.0 & 6.3 & 2.8 \\
\hline
\end{tabular}

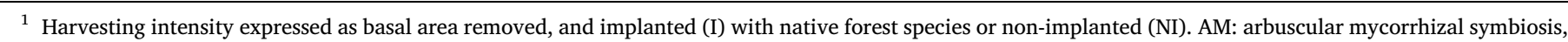
ECM: ectomycorrhizal symbiosis, MER: ericoide mycorrhizal, NH: non host mycorrhizal plants, ND: mycorrhizal types non-determined in the region. 
being for plot 1 and the lowest for plots 2, 3 and 5 (Table 2). The plants associated with AM symbiosis were Acaena sp., Azara micriphylla, Berberis buxifolia, Chusquea culeou, Cynanchum descolei, Galium hypocarpium, Geranium magellanicum, Lomatia hirsute, Maytenus boaria, Maytenus chubutensis, Mutisia spinosa, Ribes cucullatum, Schinus patagonicus, Vicia nigricans, and Blechnum sp. These AM species presented the highest soil cover in each plot (Table 2). The highest values were observed in plot 1 (98.8\%), principally associated with the presence of Maytenus chubutensis and Berberis buxifoli; in plot 8 (51\%) the value was related to Blechnum sp. and Acaena sp. These species also contributed to the intermediate cover values (between 30 and 10\%) with the presence also of Berberis buxifolia and Ribes magellanica. The ECM Nothofagus antarctica and ERM Gaultheria mucronata showed lower cover values. The ECM had 1.3 and $0.8 \%$ in plots 1 and 3, and the remaining plots had undetectable cover (0\%). Gaultheria mucronata, an ERM species, had cover values of 0.5 and $3.0 \%$ in plots 4 and 5 respectively.

In general, El Foyel soil was slightly acidic ( $\mathrm{pH} 5.5$ ), with the following average values: electrical conductivity of $110 \mu \mathrm{cimen} \mathrm{cm}^{-1}$, gravimetric humidity $25.13 \%, 0.46 \%$ of $\mathrm{N}$, and $7.51 \%$ of C. Available P was $7.02 \mu \mathrm{g} \mathrm{g}^{-1}$ soil, and the Ca quantity was $0.31 \%$. When comparing soil parameters between seasons, autumn values for gravimetric humidity, $\mathrm{pH}, \mathrm{EC}$, and $\mathrm{N}$ were all higher than in summer (humidity: 32.71-19.44\%; $\mathrm{F}=119.8, p=<0.0001 ; \mathrm{pH}: 5.94-5.17 ; \mathrm{F}=43.3$, $p=0.0001$; EC: $138.22-89 \mu$ cimen $\mathrm{cm}^{-1} ; \mathrm{F}=48.6, p=0.0001 ; \mathrm{N}$ : $0.5-0.43 \% ; \mathrm{F}=7.5, p=0.02$; Table 3 ). There were no differences between season in the amount of $\mathrm{C}, \mathrm{P}$ and $\mathrm{Ca}$ (C: $8.2-7 \%$; $\mathrm{F}=4.5$, $p=0.06$; P: 7.87-6.39 $\mathrm{gg} \mathrm{g}^{-1} ; \mathrm{F}=4.42, p=0.06$; Ca: $0.33-0.29 \%$; $\mathrm{F}=4.7, p=0.06$ autumn and summer respectively, Table 3 ). The only soil variable that showed differences related to forest management was available $\mathrm{P}$ (harvesting intensity: $\mathrm{F}=0.003, p=0.9$; implantation: $\mathrm{F}=0.5, p=0.5$; harvesting intensity: implantation: $\mathrm{F}=9.2, p=0.01$ ). It was observed that an increase in harvesting intensity in implanted plots led to an increase in $\mathrm{P}$, while in non-implanted plots $\mathrm{P}$ values diminished when harvesting was intensified (Supplementary Fig. 1).

\subsection{Community analysis in relation to seasonality and forest management}

\subsubsection{Diversity indices}

A total of 119,235 fungal sequences were generated from the soil, which after the filtering process and removal of singletons constituted 55,345 sequences. These sequences were grouped into 1848 OTUs. The average sequences and number of OTUs per plot $(n=16)$ were 3459 and 485 respectively, without considering the difference between seasons.

Considering the diversity indices, the global Simpson equitability was 0.98 , the Shannon-Weaver diversity was 4.98 , and Chao1 estimated richness was 659 (Fig. 1 and Table 4). The OTU rarefaction curves for all data sets reached the asymptote (Fig. 1). Species richness estimates were similar for both seasons and presented superposition of the estimated curves (Fig. 1).

Considering the total dataset (1848 OTUs), over 50\% (1047) were shared between the two seasons, while 385 were found exclusively in autumn and 416 only in summer. The between-season Bray-Curtis similarity index was 0.66 (Table 4).

Analysis using the statistical models showed that neither fungal richness parameters (expected or estimated) were influenced by the intra-annual seasonality factor. However, an effect was observed when interaction between the two forest management factors was analyzed (implantation: harvesting intensity: harvesting intensity ${ }^{2}$ ) (Fig. 2 and Supplementary Table 1). In the implanted plots, richness (OTU observed) was similar for 0 and 0.3 harvesting intensities, and these values were lower than the other harvesting intensities. A similar tendency was observed for estimated richness, with a high number of OTUs in the 0.5 and 0.7 harvesting intensities. In non-implanted plots, the estimated and expected richness values behaved in the same way, with the highest values found for 0.3 harvesting intensity (Fig. 2). The statistical analysis of Simpson equitability and Shannon-Weaver diversity indices showed that there was no effect on fungal richness due to season or forest management (harvesting and implantation) (Fig. 2 and Supplementary Table 1).

\subsubsection{Taxonomic classification}

Of the 1848 OTUs obtained, $3(0.1 \%)$ were not assigned to kingdom level and 245 (13\%) were classified only to Fungi kingdom level. The remaining 1600 OTUs and 51,667 sequences were classified into 5 phyla ( $87 \%$ of OTUs and $93 \%$ of sequences), 18 classes ( $72 \%$ of OTUs and $79 \%$ of sequences), 61 orders ( $62 \%$ of OTUs and $68 \%$ of sequences), 103 families (49\% of OTUs and $57 \%$ of sequences), 207 genera (37\% of OTUs and $44 \%$ of sequences) and 194 species ( $17 \%$ of OTUs and $32 \%$ of sequences).

Analysis of the effects of intra-annual seasonality on the fungal community at site level revealed that at phylum level an inversion of dominance was observed between seasons: Ascomycota fungi predominated in autumn, increasing from $42 \%$ in summer to $49 \%$ in autumn, while Basidiomycota showed an increase in summer, rising from $36 \%$ in autumn to $45 \%$ in summer. The third most abundant phylum in both seasons was Zygomycota (7 and 5\% in autumn and summer, respectively) (Fig. 3a). The most abundant classes in both seasons were Agaricomycetes (Basiomycetes), followed by Leotiomycetes, Sordariomycetes (both Ascomycetes), and Tremellomycetes (Basidiomycetes). In autumn there was an increase in the abundance of Leotiomycetes, Sordariomycetes, and Tremellomycetes. In contrast, Agaricomycetes displayed an increase in abundance in summer (Fig. 3b). The most abundant orders in both seasons were Agaricales (Agaricomycetes) and Helotiales (Leotiomycetes) with sequence abundances of $12-22 \%$ for Agaricales in autumn and summer respectively, and 13-11\% for Helotiales in autumn and summer, respectively. In autumn the orders Mortierellales (Mortierellomycetes) and Filobasidiales (Tremellomycetes) presented sequence abundances of 7 and $6 \%$, respectively, which decreased to values $<5 \%$ in summer (Fig. $3 \mathrm{c}$ ).

Community structure: At plot level, the ordering study (NMDS analyses) between phylum assignation, forest management, season, and soil characteristics showed no correlation between phylum and season, phylum and harvesting intensity or implantation. However, a statistical relationship was observed between phylum and soil chemical properties (Fig. 4a). The increase in Ascomycota was related to the increase in $\mathrm{C}$ $\left(p=0.032^{*}\right), \mathrm{N}\left(p=0.02^{*}\right)$, and EC $\left(p=0.015^{*}\right)$, while the increase in Zygomycota was associated with higher humidity $\left(p=0.02^{*}\right)$. When considering plot and class level, correlations were observed only with season $\left(p=0.004^{* *}\right)$, humidity $\left(p=0.001^{* *}\right)$, EC $\left(p=0.007^{* *}\right)$, and $\mathrm{pH}\left(p=0.03^{*}\right.$; Fig. $\left.4 \mathrm{a}\right)$; there was no correlation with harvesting or implantation (Fig. 4b). In autumn the plots had higher soil humidity, $\mathrm{EC}$, and $\mathrm{pH}$, and these plots were correlated with Leotiomycetes, Sordarimycetes, and Tremellomycetes. In contrast, the summer plots were associated with Dothideomycetes, Eurotiomycetes and Agaricomycetes (Fig. 4b). The NMDS analysis of the orders at plot level showed correlations between some soil chemical characteristics, but no correlations were evidenced for the season and management variables (harvesting and implantation; Fig. 4c). The chemical characteristics of the soil that showed correlations were: EC $\left(p=0.013^{*}\right)$, humidity $\left(p=0.025^{*}\right), \mathrm{N}$ $\left(p=0.002^{* *}\right), \mathrm{C}\left(p=0.003^{* *}\right)$, and available $\mathrm{P}\left(p=0.026^{*}\right.$; Fig. $\left.4 \mathrm{c}\right)$. The results obtained with distance-based $R D A$ were similar to envfit (not shown).

\subsubsection{Ecological guild characterization at species level}

The genera and species frequencies were poorly represented with respect to the total data (as mentioned in the previous section). However, in order to analyze the ecological guilds of the assigned species, the distribution of genera and species followed these patterns: in autumn the most numerous genera (more than 500 sequences) were: Ilyonectria (1694 sequences), Mortierella (1597), Cryptococcus (1479), Hygrocybe (1321), Lecythophora (607), and Trichocladium (607), 


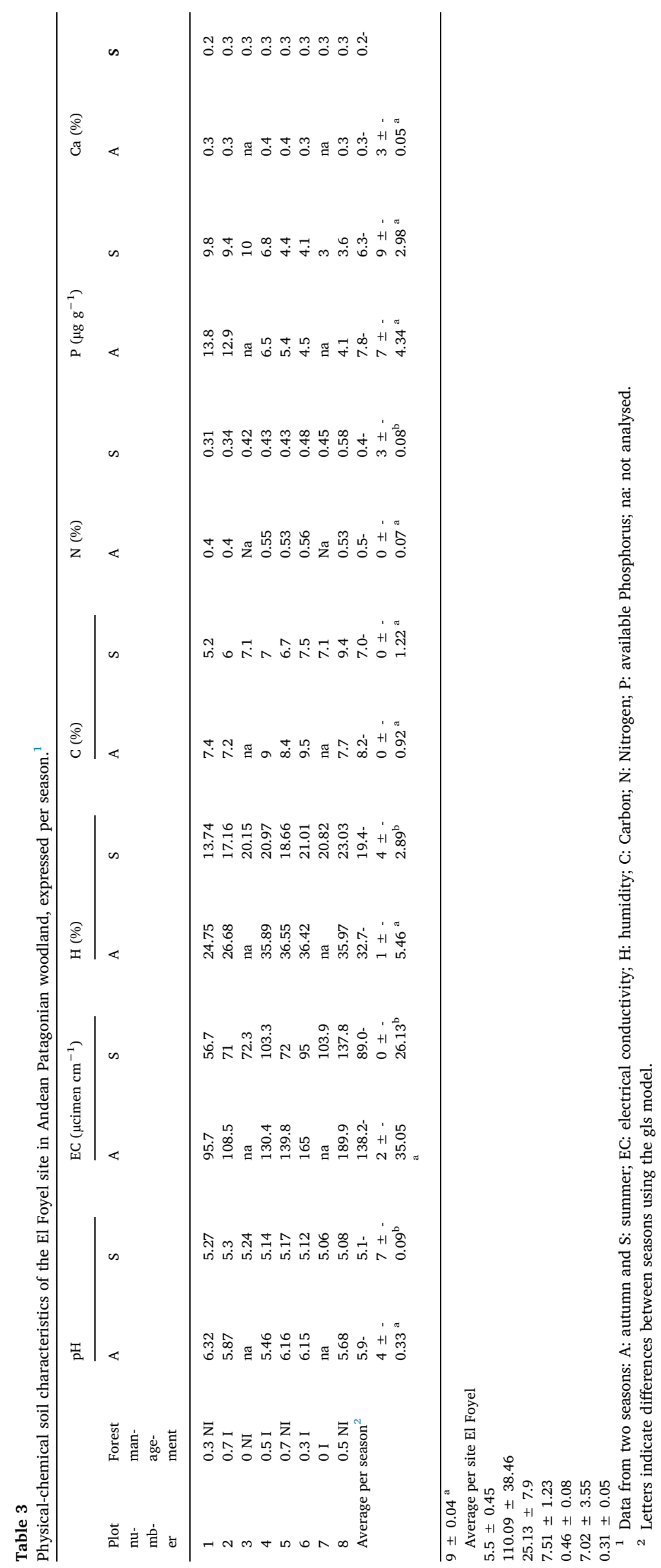




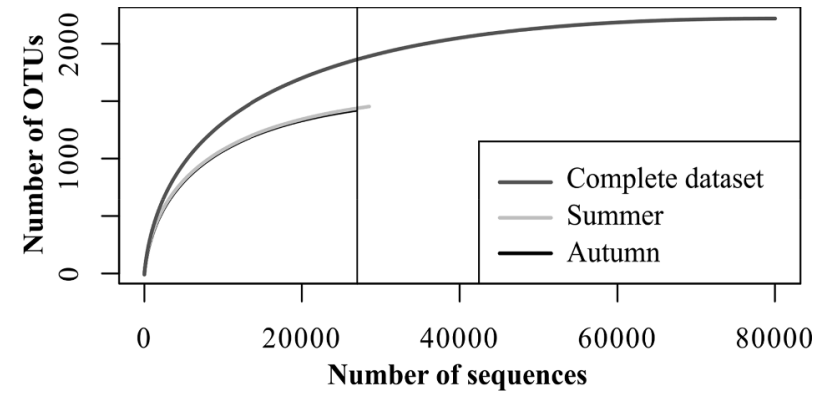

Fig. 1. Rarefaction curve for the complete OTU dataset $(n=16)$ and for each season $(n=8)$, summer and autumn. The rarefied OTU richness values were for the complete dataset $=1868$, summer $=1445$ and autumn $=1432$.

Table 4

Average values for total and seasonal soil fungal data and the diversity index of El Foyel Patagonian woodland.

\begin{tabular}{|c|c|c|c|}
\hline & Autumn + Summer & Autumn & Summer \\
\hline Abundance $^{1}$ & $3459 \pm 361$ & $3350 \pm 453$ & $3568 \pm 219$ \\
\hline Number of shared OTUs & 1047 (56.75\%) & & \\
\hline $\begin{array}{l}\text { Number of non-shared } \\
\text { OTUs }\end{array}$ & & $385(20.8 \%)$ & $416(22.5 \%)$ \\
\hline Expected richness $^{2}$ & $485 \pm 43$ & $475 \pm 40$ & $495 \pm 47$ \\
\hline Estimated richness ${ }^{3}$ & $659 \pm 59$ & $661 \pm 57$ & $658 \pm 67$ \\
\hline Equitability Index & $0.98 \pm 0.006$ & $0.98 \pm 0.006$ & $0.98 \pm 0.007$ \\
\hline Diversity Index & $4.98 \pm 0.2$ & $4.95 \pm 0.16$ & $5.01 \pm 0.24$ \\
\hline Similarity Index & & 0.66 & \\
\hline
\end{tabular}

\footnotetext{
1 Number of sequences.

2 Observed OTUs.

3 Estimated OTUs.
}

represented principally by the species Ilyonectria rufa, Hygrocybe conica, Mortierella verticillata, Cryptococcus terreus, Lecythophora mutabilis, Mortierella spp., Trichocladium opacum, and Cryptococcus terricola
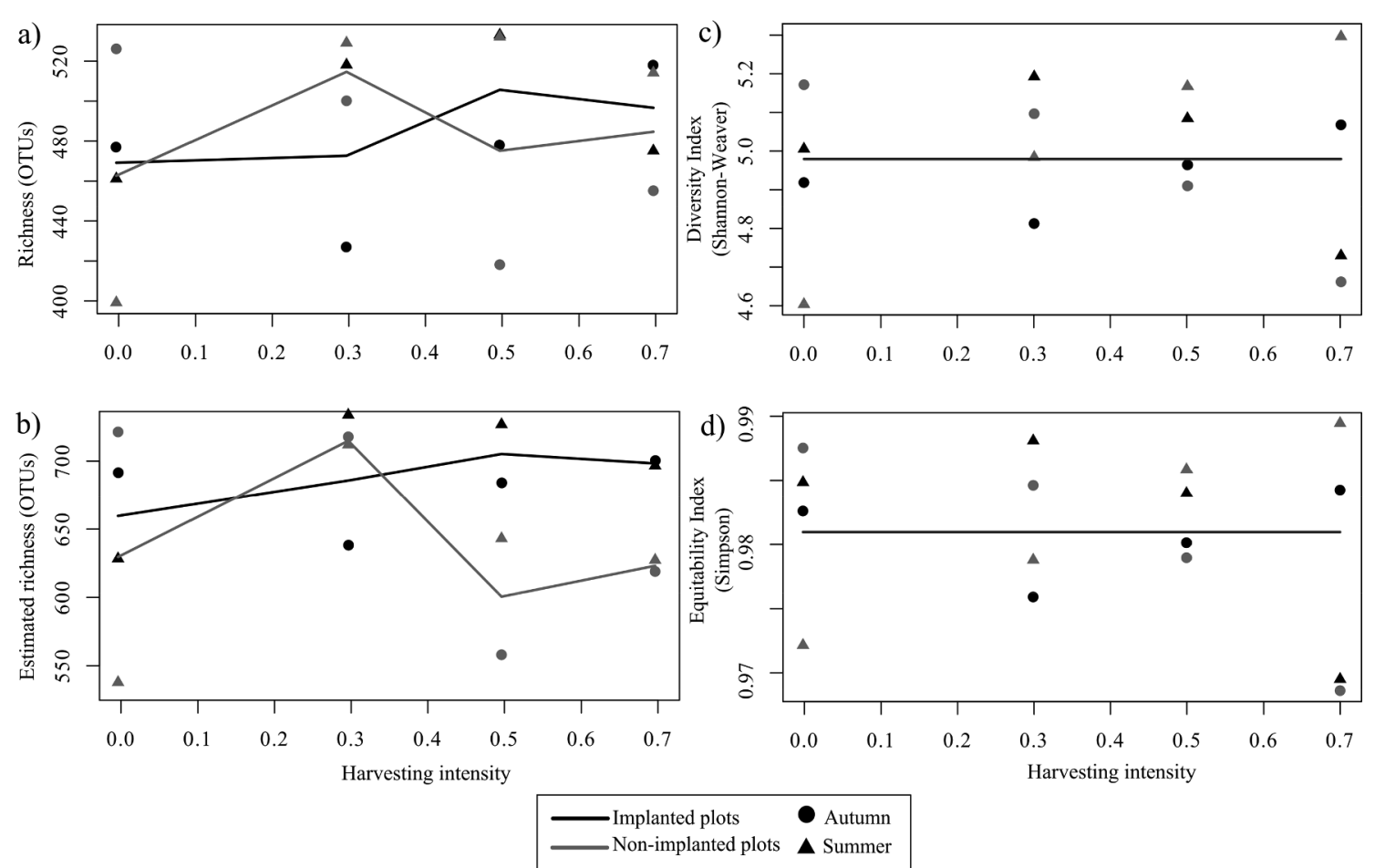

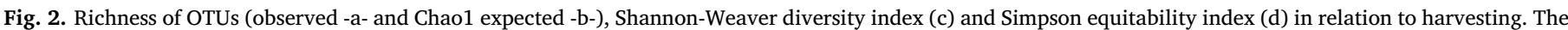

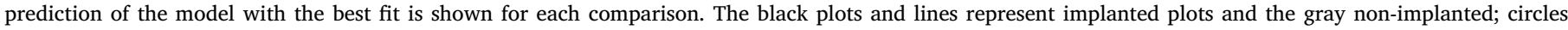
represent autumn data and triangles represent summer.

(Supplementary Table 2). In summer the most numerous genera were Hygrocybe (1983), Mortierella (1237), Cryptococcus (830), Cortinarius (699), Ilyonectria (653), Clitopilus (638), Lecythophora (593), and Geoglossum (527), and the species were Hygrocybe conica, Mortierella verticillata, Cortinarius spp., Clitopilus hobsonii, Ilyonectria rufa, Lecythophora mutabilis, and Cryptococcus terreus (Supplementary Table 2).

Of the 207 genera, 170 were assigned to ecological guilds (with highly probable and probable confidence). The saprotroph ecological guild presented the highest sequence abundance ( 49 and $59 \%$ in autumn and summer respectively), followed by plant pathogens (22-12\% in autumn and summer respectively), other symbionts (12-11\% in autumn and summer respectively), and ectomycorrhizal fungi (10-13\% in autumn and summer respectively; Fig. 5 a). Since the primers used were not able to identify the community of Glomeromycetes well, and the assignation to AM fungi represented $<1 \%$ of the total phyla and of ecological guild assignment in autumn and summer respectively, they were not included in this analysis (see Materials and methods, taxonomic fungal classification).

At plot level, the NMDS study was performed between ecological guilds, forest management, season, and soil chemical characteristics. Correlations were found between seasons $\left(p=0.016^{*}\right)$ and soil chemical characteristics: humidity $\left(p=0.002^{* *}\right)$, EC $\left(p=0.002^{* *}\right)$, C $\left(p=0.001^{* * *}\right)$ and $\mathrm{N}\left(p=0.001^{* * *}\right.$; Fig. 5 b). Autumn was related to increased values for plant pathogens and an increase in humidity, EC, C, and $\mathrm{N}$, while summer was associated with saprotroph, other symbionts, and ectomycorrhizal fungi, and a decrease in soil characteristics (Fig. 5 b).

\section{Discussion}

The mixed woodland of the experimental program presented vegetation typical of this environment (as mentioned in the introduction) with low and young trees and high shrubs. Although each plot had certain particular characteristics with respect to the abundance of vegetation, in general the higher cover levels were determined by more or

anted plots $\boldsymbol{\Delta}$ Summer 


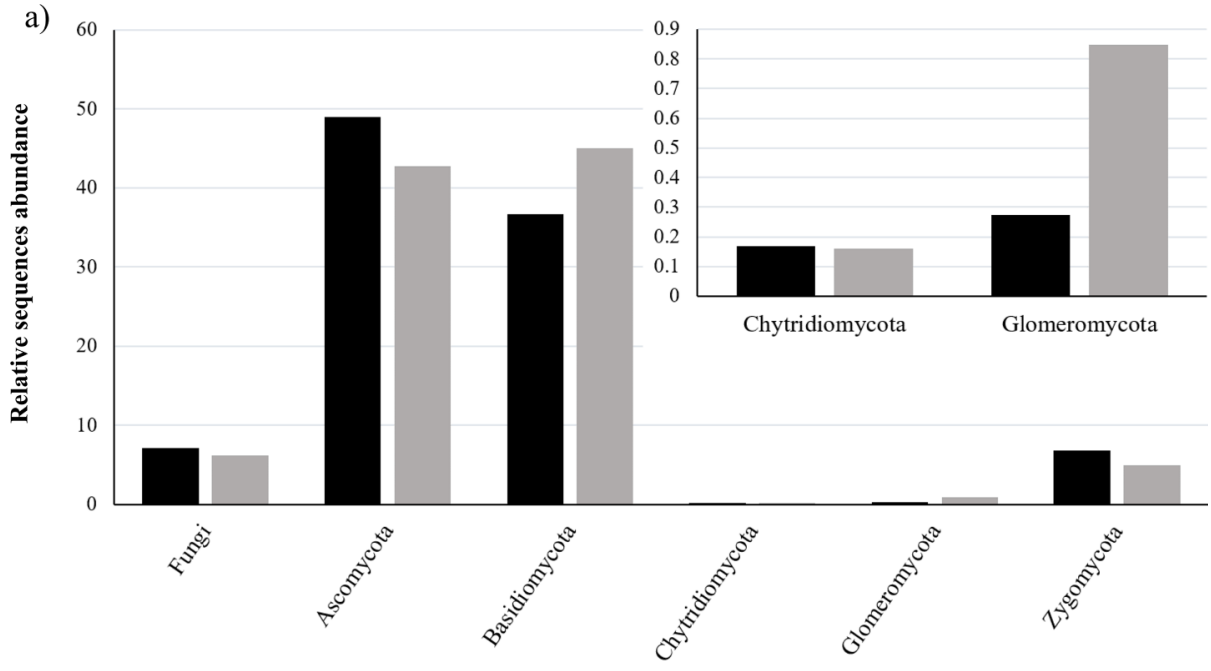

b)

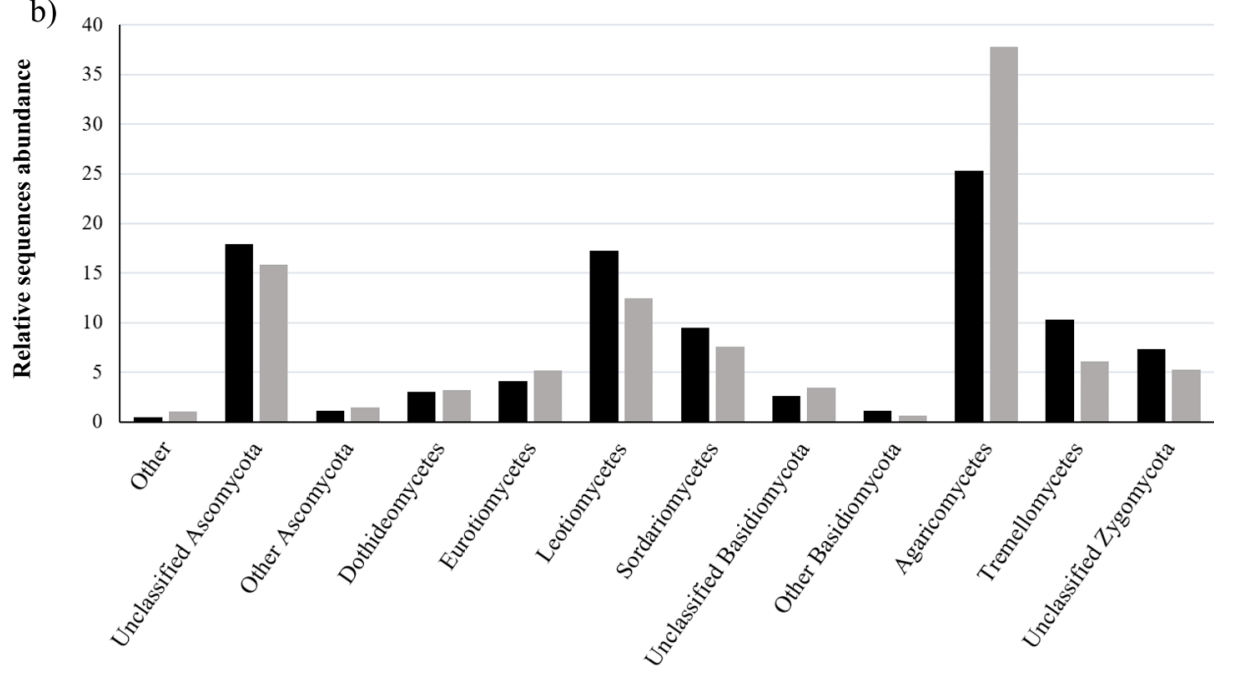

c)

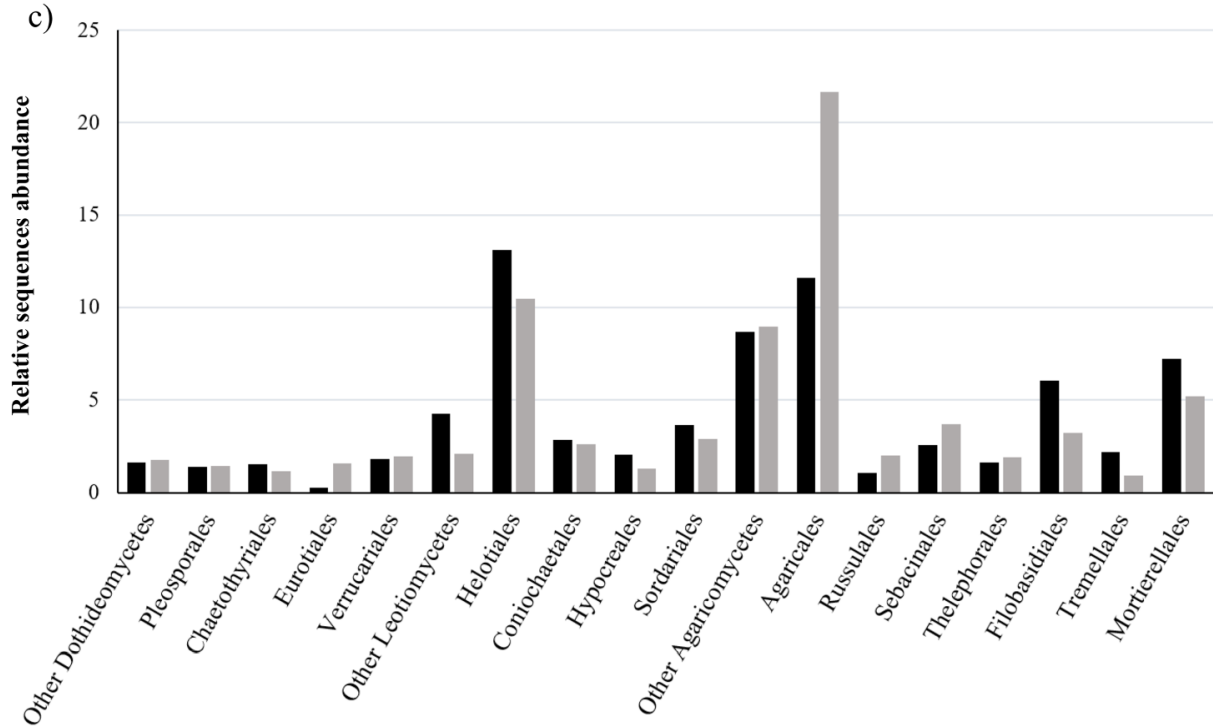

Fig. 3. Relative abundance of sequences assigned to phyla (a), classes (b), and orders (c), in both seasons. Unclassified classes included sequences grouped into their respective phyla, as they were not identified to class level. "Others" includes classes and orders with an abundance less than $1 \%$. In (b) "Others" include: Chytridiomycetes, Monoblepharidomycetes, and Glomeromycetes; "Other Ascomycota" include: Archaeorhizomycetes, Lecanoromycetes, Orbiliomycetes, Pezizomycetes, and Saccharomycetes; "Other Basidiomycota" include: Agaricostilbomycetes, Dacrymycetes, Entorrhizomycetes, and Microbotryomycetes. In (c) "Other Dothideomycetes" include: Dothideales and Capnodiales; "Other Leotiomycetes" include: Erysiphales, Leotiales, and Thelebolales; "Other Agaricomycetes" include: Atheliales, Auriculariales, Boletales, Cantharellales, Corticiales, Geastrales, Gomphales, Hysterangiales, and Polyporales.

Autumn Summer

less the same species, with a predominance of Maytenus chubutensis and shrub species. It has previously been reported (Fernández et al., 2012; Fontenla et al., 1998, 2001; Velázquez et al., 2016; Godoy and Marín, 2019) that AM plants are the most abundant in the native forest of North Patagonia, not only in forest where the dominant tree species had
AM, such as those dominated by ECM native species, Nothofagus spp. In the mixed woodland analyzed here, the species with highest cover were associated with AM symbiosis. In another study, carried out in the same experimental management program between October 2014 and January 2015 , it was found that the most abundant floral plant species 
a)

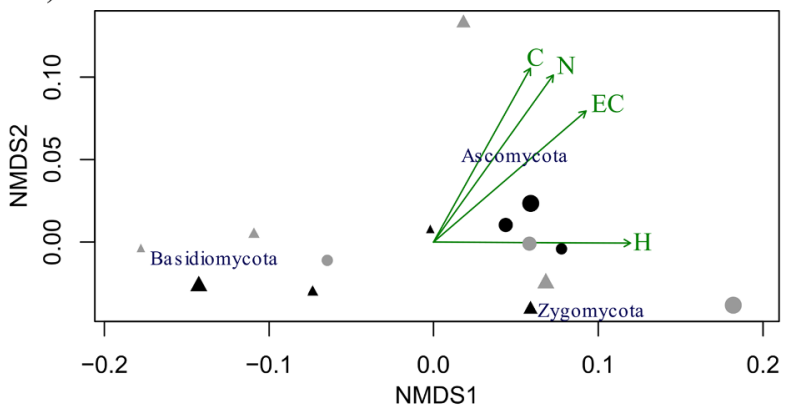

c1)

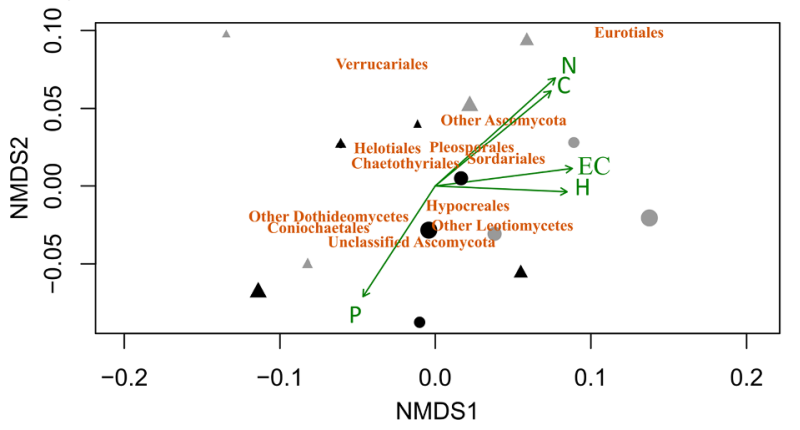

b)

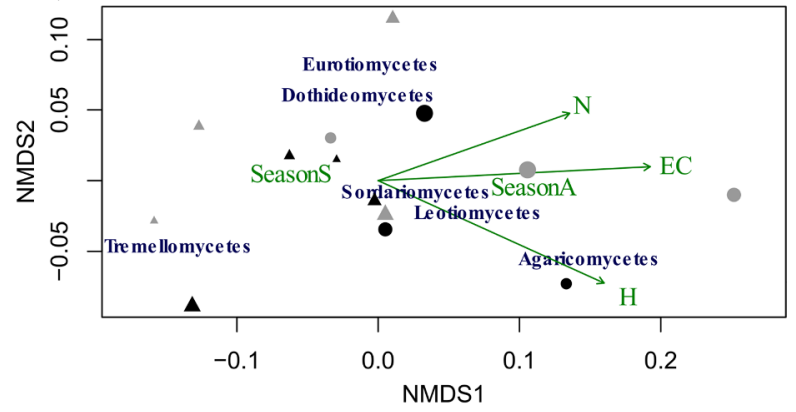

c2)

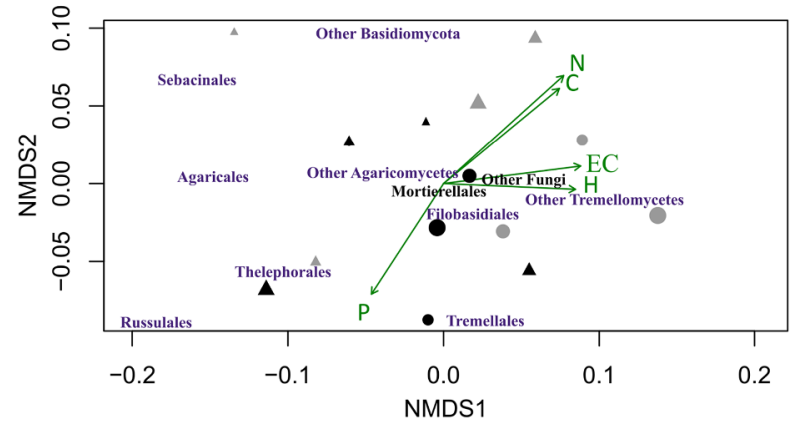

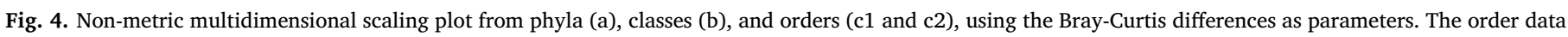

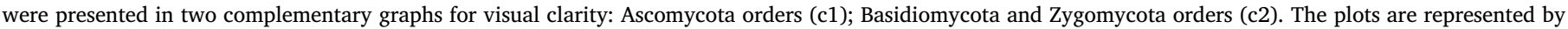

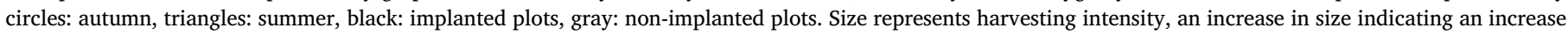

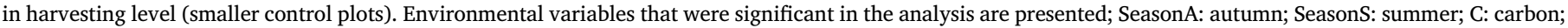
$\mathrm{N}$ : nitrogen; H: humidity; P: phosphorus; EC: electric conductivity.

were woody, including D. chacaye, S. patagonicus, and Maytenus sp., and that plant density decreased in the plots with increasing harvesting intensity, while plant richness increased with an increase in harvesting level (Coulin et al., 2019).

In general, the site had slightly acidic soil, with values of $\mathrm{N}$ and $\mathrm{C}$ consistent with those obtained in different native forests from similar regions in Northwest Patagonia (Diehl et al., 2003; Alauzis et al., 2004; Chaia et al., 2006; Satti et al., 2007). When the seasonal effect was analyzed, differences were revealed in some soil chemical characteristics: gravimetric humidity, mainly related to the increase in rainfall at autumn, and $\mathrm{pH}, \mathrm{EC}$, and $\mathrm{N}$ (Table 2). Ca and available P did not show statistically significant seasonal changes. Previous studies in forest soil of the region reported statistical differences in available $\mathrm{P}$ between seasons (Satti et al. 2007; Diehl et al., 2008), which may constitute another difference between this mixed woodland and forest dominated by other Nothofagus species.

Several studies have shown that soil chemical and physical characteristics are modified with changes in land use (McDowell and Stewart, 2006; Klein et al., 2008; Lauber et al., 2008; Dube et al., 2009; Redel et al., 2015). When analyzing the effect of forest management, available $\mathrm{P}$ was the only soil parameter that showed significant differences (Supplementary Fig. 1). This was in accordance with studies in Nothofagus forests in southern Chile, where a decrease in different phosphorus fractions was found, in particular available $\mathrm{P}$, with the application of forest management (Redel et al., 2008) and other landuse changes (Redel et al., 2015).

Taxonomic classification of the community showed a high number of unidentified sequences (Buée et al., 2009; Truong et al., 2017), suggesting a considerable number of undescribed fungi for these environments, as previously mentioned by other authors in the region (de Garcia et al., 2012; Duo Saito et al., 2018). It also important to considerer that nowadays new NGS methods are used, which could produce novel or more detailed analyses than considered here using 454-pyrosequencing (Roche) platforms (Henrik Nilsson et al., 2011; Lindahl et al., 2013; Oulas et al., 2015). The Shannon-Weaver diversity index presented values close to 4.5 in both seasons (Table 4). These values were lower than those found by Fernández et al. (2018), with a diversity value of 0.84 for the rhizosphere of total fungi in $N$. pumilio forests, and around 0.95 for the area affected by the tephra fall. The number of total fungal genomic studies in the Northwest Patagonia is small, with very few that address subject of forest management, but these suggest that mixed woodland could have an intermediate diversity value.

The community analysis (richness, Shannon-Weaver, and Simpson indexes) showed that these factors were similar between seasons. More than half of the OTUs (57\%) were shared between the two seasons, and the Bray-Curtis similarity index was 0.66 . These results are comparable to those cited by Purahong et al. (2015) in temperate Fagus sylvatica forests of the central region of Germany (studied over a complete year, in each season) where they found that approximately $44-55 \%$ of the fungal OTUs were shared between the different types of forest cutting.

At a fungal community level, neither the equity nor diversity indices showed a significant management effect. When considering richness, a significant effect was observed in the interaction between harvest intensity and implantation (Fig. 2). Our results partly contradict Goldmann et al. (2015) who studied different forest management strategies of Fagus sylvatica, Picea abies, and Pinus sylvestris in Germany, and found that in general the study site and the type of forest management had no effect on fungal diversity and richness.

In our work, when analyzing the taxa between seasons, a tendency of an inversion of dominance was observed: Ascomycota increase in autumn, and Basidiomycota in summer. This data partially overlaps with studies in cold regions in both hemispheres, in spring and summer, where it has been reported that Ascomycetes were the dominant phylum in soils (Goldmann et al., 2015; Duo Saito et al., 2018). It has been documented also that Basidiomycota, and to a lesser extent Ascomycota fungi, are predominant in forest soils in different regions of the world (Tedersoo et al., 2014; Voriskova et al., 2014) and in similar 

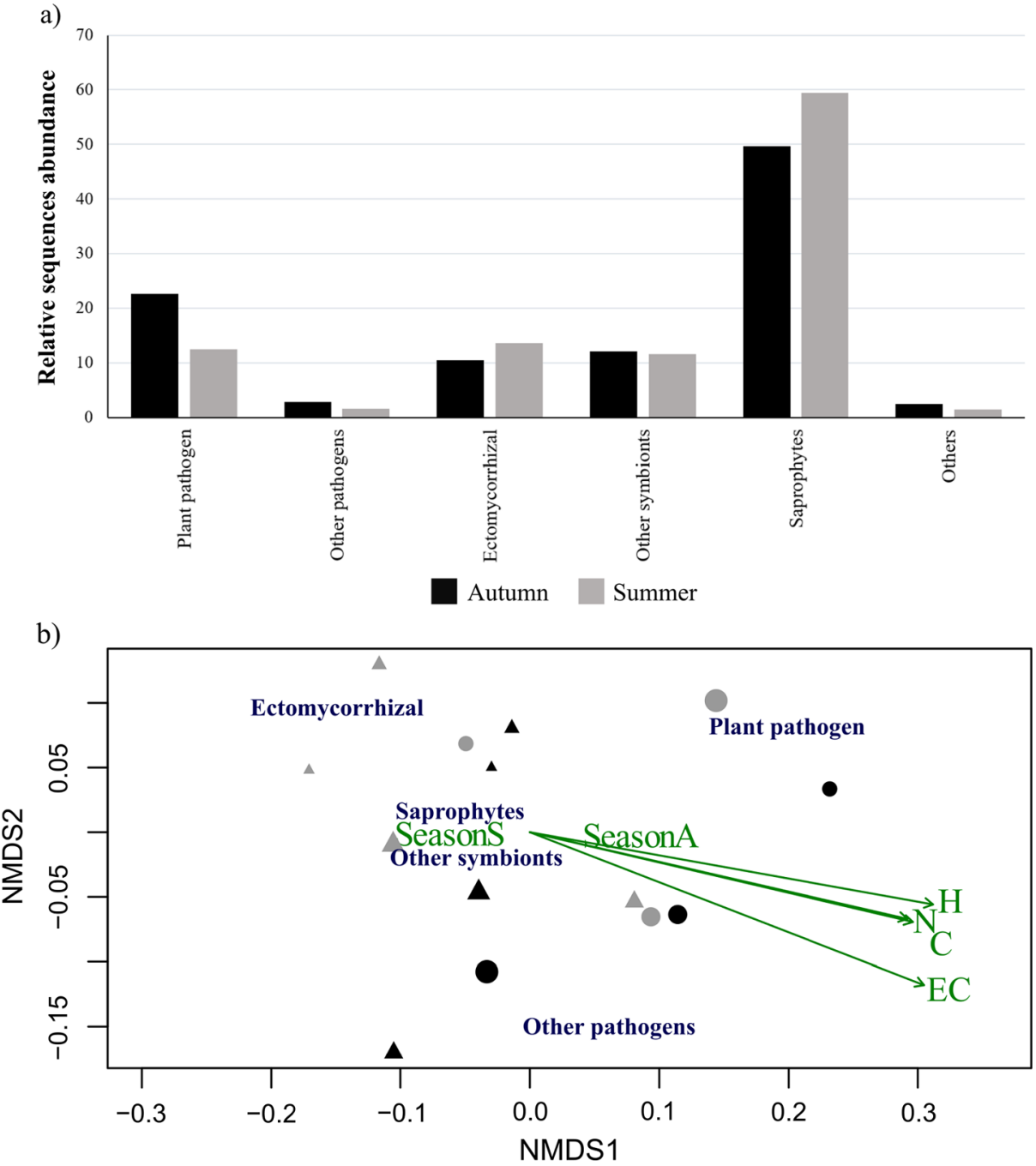

Fig. 5. Relative abundance of sequences (a) and non-metric multidimensional scaling (b) assigned to ecological guilds. In (a) "Others" includes: Animal endosymbiont-Undefined saprotroph, Endophyte-Wood saprotroph, Animal pathogenEndophyte-Fungal parasite-Lichen parasite-Plant pathogen-Wood saprotroph, Fungal parasite, and Lichen. In (b) the plots are represented by circles: autumn, triangles: summer, black: implanted plots, gray: non-implanted plots. Size represents the harvesting intensity, an increase in size indicating an increase in harvesting level (smaller control plots). Environmental variables that were significant in the analysis are presented; SeasonA: autumn; SeasonS: summer; C: carbon; N: nitrogen; H: humidity; EC: electric conductivity. regions to that studied in this work (Marín et al., 2017). In addition, yeasts from these groups have also been cited in soil (Mestre et al., 2014), in aquatic environments (Libkind, 2006), and in N. nervosa fruits (Fernández et al., 2012) in the region. The Glomeromycota showed very little representation of sequences and OTUs in this study and were not analyzed, since the primers used (ITS1F and ITS2) are not effective for amplification of this group of fungi (Stockinger et al., 2010; Schoch et al., 2012).

The most abundant classes in both seasons were the Agaricomycetes, followed by Leotiomycetes, Sordariomycetes, and Tremellomycetes. These results could partially overlap with the work of Marín et al. (2017) and Duo Saito et al. (2018). Marín et al. (2017) found that in general Agaricomycetes, Dothideomycetes, and Sordariomycetes were the most abundant soil fungus classes in Nothofagus forests of Chile. Furthermore, Duo Saito et al. (2018) found that in naked soil near glaciers the Leotiomycetes were the most common taxon, followed by Sordariomycetes, Dothideomycetes, and Eurotiomycetes. In their global study, Tedersoo et al. (2014) found that Agaricomycetes and Tremellomycetes presented peaks of richness at mid-latitudes, whereas Sordariomycetes presented a maximum peak in tropical ecosystems and Leotiomycetes did so towards the poles. Our results could partially overlap with this global behavior, considering the latitude and climatic conditions of the area. In our work, the mixed woodland in autumn presented an increase in the number of sequences of Leotiomycetes, Sordarimycetes, and Tremellomycetes, and these were correlated with an increase in humidity, conductivity, and $\mathrm{pH}$ (Fig. 4b). In the summer, Agaricomycetes, Dothideomycetes and
Eurotriomycetes showed an increase in number of sequences. These results are in agreement with the work done in $N$. betuloides forests in Chile (Marin et al., 2017).

The most abundant orders in both seasons were Agaricales (Agricomycetes) and Helotiales (Leotiomycetes), followed by Mortierellales (Mortierellomycetes) and Filobasidiales (Tremellomycetes). Agaricales, Helotiales and Mortierellales presented high percentages of abundances in other works (Lim et al., 2010; Sterkenburg et al., 2015, Zhang et al., 2016; Truong et al., 2019), and Agaricales have high diversity in the Patagonian Nothofagus forests when compared with European Fagus forests (Marín et al., 2017; Godoy and Marín, 2019). Chemical properties of the soil, such as gravimetric humidity, EC, C, N, and available P, were modelers of the fungal community at different taxonomic levels (Fig. 4).

If we consider the genera and species assigned instead of the low representative values, the most numerous genera shared in both seasons were: Hygrocybe, Mortierella, Cryptococcus, Ilyonectria, and Lecytophora; in autumn the genus Trichocladium was also important, as were Cortinarius and Clitopilus in summer. The most numerous species in autumn were Hygrocybe conica, Ilyonectria rufa, Mortierella verticillata, and Cryptococcus terreus, and in summer Hygrocybe conica, Mortierella verticillata, Cortinarius spp., Clitopilus hobsonii, and Ilyonectria rufa. The genus Hygrocybe was described as a saprotroph-symbiotroph, and its carbon signature suggests plant biotrophy, including bryophytes (Seitzman et al., 2011; Halbwachs et al., 2013; Tello et al., 2013; Lodge et al., 2014). The genera Clitopilus, Geoglossum, Mortierella, and Trichocladium are classified as saprophytes (Tedersoo et al., 2014; Truong 
et al., 2019). It has been found that the yeasts of the genus Cryptococcus were associated with soil nutrient cycles and with plants, acting as promoters of plant growth (Cloete et al., 2009; Mestre et al., 2016). The species of genus Cortinarius and Lecythophora are symbionts, the former being ectomycorrhizal fungi (Rinaldi et al., 2008) and the latter dark septate endophytes (Taylor et al., 2014). Finally, species of the genus Ilyonectria have been reported as pathogenic, causing the disease of root rot (Chaverri et al., 2011; Cabral et al., 2012) and have been found as an endophyte in asymptomatic plants (White et al., 1962). With the limitations of the low representative values of these two taxa, and until further identification is made or new identification methodologies are used, it seems that most of the abundant sequences were principally related to saprotrophs and symbiotrophs related to summer and lower soil values of $\mathrm{C}$ and $\mathrm{N}$, maybe associated, and pathotrophs. Also, for definitive conclusions is would be necessary to consider the important AM fungi group, particularly because all the plots had higher soil cover associated AM plants.

In our work we found a correlation between soil characteristics and ecological guilds (Fig. 5 b), but not with management. The NMDS analysis revealed that the ecological guilds, in autumn there was an increase in the sequences pathogens (i.e. plant pathogens such as Ilyonectria) and other symbionts, related with high values of $\mathrm{C}$ and $\mathrm{N}$. In summer there was an increase in the sequences of saprotrophs and ectomycorrhizal fungi, which could be related to the increase in sequences of Cortinarius, one of the most abundant genera in Nothofagaceae forest (Hewitt et al., 2018; Truong et al., 2019). Marín et al. (2017) saw an inverse relationship between pathotrophs and symbiotrophs, related to the use of land; in plots with intense use ( $=$ total removal of vegetation) pathogens were more abundant, and the pristine, managed (= partial removal of vegetation) plots had higher mycorrhizal fungal abundance. Tedersoo et al. (2014) recorded the effect of $\mathrm{pH}$ and the plant community on ectomycorrhizal fungi, and the effect of the distance from the equator and soil $\mathrm{C} / \mathrm{N}$ ratio for pathogens, and suggested that the richness of fungi and functional groups is unrelated to plant diversity, with the exception of ectomycorrhizal fungi, since plant-soil feedbacks does not influence the diversity of soil fungi on a global scale. In these work we also could bear in mind that the FUNGuild platform depends, to a large extent, on precise taxonomic identification and many OTUs were placed in the unassigned group for the incomplete database (Nguyen et al., 2016).

The mixed woodlands of Andean-Patagonian forests constitute an important habitat characterized by representative plant species of this region and some of the Patagonian steppe, with a high level of biodiversity and ecosystem services (Larreta et al., 2017; Rusch et al., 2017). However, these, mixed woodlands are considered usable zones for current forest activities (Gowda et al., 2014; Grosfeld et al., 2019), and are underrepresented in terms of protection measures (for example, they are underrepresented in the National Parks system of Argentina). These attributes represent an opportunity for social and economic development of forestry activities in the region, but these activities must be regulated because of the high ecological value of this environment (Rusch et al., 2017; Grosfeld et al., 2019). For this reason, further research should be carried out to establish sustainable management plans that guarantee the best use and maintenance of these resources. These results suggest that diverse factors, such as those analyzed here, modify the fungal community structure at different taxonomic levels and ecological guild, but not the management at one year of done. Further research, with other sequencing technology and an expanded database of the ecological guilds, is required to clarify how these microbial groups are affected over time by management of this environment.

\section{Conclusion}

This study contributes to the knowledge of woodland fungal communities in the Northwest Patagonian region, and is one of the first basal studies to show the effect of forest management on the soil fungal community in a mixed woodland. The work is novel due to its experimental approach in a native environment. At site level, the mixed woodlands appear to have soil chemical characteristics similar to other forest environments in the same region, but could have intermediate fungal diversity than forests, which could be attributed to the high plant diversity of these environments. This work revealed a high number of new or non-identified fungi, highlighting the fact that this environment has been little studied, and the importance of doing so.

When the seasonal effect was analyzed, no changes were observed in the diversity of the fungal communities (evaluated by richness and diversity index), whereas modifications were recorded in the taxonomy and ecological guilds of the community, and in certain soil parameters (gravimetric humidity, $\mathrm{pH}, \mathrm{EC}, \mathrm{C}$, and $\mathrm{N}$ ); the changes in the proportions of abundant taxa should be considered.

When considering forest management, in general the fungal community (diversity indexes, taxonomy, and ecological guilds) was not affected by this anthropic disturbance, with the exception of species richness. Available P was the only soil chemical characteristic that registered changes associated with forest management.

It should be highlighted that available $P$ and species richness could be proposed as bioindicators. Future studies considering more results from this kind of native program and other aspects such as vegetation, use and system functions of the area, will allow us to assess whether some of these changes are early bioindicators of sustainable use and management.

Future studies with analysis over a longer period of time following management, and a greater number of experimental assays, could also complement the conclusions of this work. Questions remain as to how resilient soil fungi are in the face of disturbances such as forest management, whether they constitute a positive response strategy, and how the duration of the management period influences the system.

\section{CRediT authorship contribution statement}

Ayelen Inés Carron: Conceptualization, Methodology, Software, Formal analysis, Data curation, Investigation, Writing - original draft, Writing - review \& editing, Visualization, Project administration. Lucas Alejandro Garibaldi: Conceptualization, Methodology, Formal analysis, Supervision, Funding acquisition. Sebastian Marquez: Methodology. Sonia Fontenla: Conceptualization, Methodology, Investigation, Resources, Writing - review \& editing, Supervision, Project administration, Funding acquisition.

\section{Declaration of Competing Interest}

The authors declare that they have no known competing financial interests or personal relationships that could have appeared to influence the work reported in this paper.

\section{Acknowledgements}

We are grateful to Dr. M. Cecilia Mestre, Dr. N. Fernández, Lic. D. Moguilevsky, Lic. R. Duo Saito and Mr. J. Puga for their helpful collaboration, Agronomy engineer M. Goldemberg for unpublished data, and to Dr. Luis G. Wall and two anonymous reviewers for their revision and comments. We also thank Consejo Nacional de Investigaciones Científicas y Técnicas (CONICET) for the doctoral fellowship of Lic. A.I. Carron. Financial support for this work was provided by grants: PICT 2013-1079 (FONCyT Argentina), Universidad Nacional del Comahue 04/B-200 (Argentina).

\section{Appendix A. Supplementary material}

Supplementary data to this article can be found online at https:// doi.org/10.1016/j.foreco.2020.117955. 


\section{References}

Aguirre-Calderón, O.A., 2015. Manejo forestal en el siglo XXI. Madera y bosques 21, $17-28$.

Alauzis, M.V., Mazzarino, M.J., Raffaele, E., Roselli, L., 2004. Wildfires in NW Patagonia: long-term effects on a Nothofagus forest soil. For. Ecol. Manage. 192, 131-142. https://doi.org/10.1016/j.foreco.2003.11.014.

Augé, R.M., 2001. Water relations, drought and vesicular-arbuscular mycorrhizal symbiosis. Mycorrhiza 11, 3-42.

Barton, K., 2019. MuMIn: Multi-model inference. R package version $1.43 .6<$ https:// cran.r-project.org/web/packages/MuMIn/index.html >

Baskaran, P., Hyvönen, R., Berglund, S.L., Clemmensen, K.E., Ågren, G.I., Lindahl, B.D. Manzoni, S., 2017. Modelling the influence of ectomycorrhizal decomposition on plant nutrition and soil carbon sequestration in boreal forest ecosystems. New Phytol. 213 (3), 1452-1465.

Berg, M.P., Kniese, J.P., Verhoef, H.A., 1998. Dynamics and stratification of bacteria and fungi in the organic layers of a scots pine forest soil. Biol. Fertil. Soils 26 (4), 313-322. https://doi.org/10.1007/s003740050382.

Berrios, V., Casas, C., Mayoral, L., Alvarez Soria, H.L., Perren, G., Garibaldi, L.A., 2014. Árboles nativos con potencial productive control el ambiente edáfico del matorral alto. XXIV Congreso Argentino de la Ciencia del Suelo y II Reunión Nacional "Materia Orgánica y Sustancias Húmicas". Bahía Blanca, Argentina.

Bonito, G., Reynolds, H., Robeson, M.S., et al., 2014. Plant host and soil origin influence fungal and bacterial assemblages in the roots of woody plants. Mol. Ecol. 23 (13), 3356-3370.

Brundrett, M., 2004. Diversity and classification of mycorrhizal associations. Biol. Rev. 79 (3), 473-495.

Brundrett, M.C., Tedersoo, L., 2018. Evolutionary history of mycorrhizal symbioses and global host plant diversity. New Phytol. 220 (4), 1108-1115. https://doi.org/10. $1111 /$ nph.14976.

Buée, M., Reich, M., Murat, C., Morin, E., Nilsson, R.H., Uroz, S., Martin, F., 2009. 454 Pyrosequencing analyses of forest soils reveal an unexpectedly high fungal diversity. New Phytol. 184 (2), 449-456. https://doi.org/10.1111/j.1469-8137.2009.03003.x.

Bueno, C.G., Marín, C., Silva-Flores, P., Aguilera, P., Godoy, R., 2017. Think globally, research locally: emerging opportunities for mycorrhizal research in South America: first international mycorrhizal meeting in South America, 'Mycorrhizal symbiosis in the southern cone of South America', Valdivia, Chile, 6-9 March 2017. New Phytol. 215 (4), 1306-1309.

Cabral, A., Groenewald, J.Z., Rego, C., Oliveira, H., Crous, P.W., 2012. Cylindrocarpon root rot: multi-gene analysis reveals novel species within the Ilyonectria radicicola species complex. Mycol. Prog. 11 (3), 655-688. https://doi.org/10.1007/s11557011-0777-7.

Cabrera, A.L. 1976. Regiones Fitogeográficas Argentinas. Enciclopedia Argentina de Agricultura y Jardinería. Tomo II, Fascículo 1, $2^{\mathrm{a}}$ Ed, Editorial ACME. pp. 85.

Cabrera, A.L., 1971. Fitogeografía de la República Argentina. Boletín de la Sociedad Argentina de Botánica 14, 1-42.

Cameron, E.K., Martins, I.S., Lavelle, et al., 2018. Global gaps in soil biodiversity data. Nat. Ecol. Evol. 2 (7), 1042-1043.

Caporaso, J.G., Kuczynski, J., Stombaugh, J., et al., 2010. QIIME allows analysis of highthroughput community sequencing data. Nat. Methods 7 (5), 335-336. https://doi. org/10.1038/NMETH.F.303.

Caravaca, F., Barea, J.M., Figueroa, D. Roldan, A, 2002. Assessing the effectiveness of mycorrhizal inoculation and soil compost addition for reafforestation with Olea europaea subsp. sylvestris through changes in soil biological and physical parameters. Appl. Soil Ecol. 20, 107-118.

Chaia, E.E., Fontenla, S.B., Vobis, G., Wall, L.G., 2006. Infectivity of soilborne Frankia and mycorrhizae in Discaria trinervis along a vegetation gradient in Patagonian soil. J. Basic Microbiol. 46 (4), 263-274. https://doi.org/10.1002/jobm.200510095.

Chaverri, P., Salgado, C., Hirooka, Y., Rossman, A.Y., Samuels, G.J., 2011. Delimitation of Neonectria and Cylindrocarpon (Nectriaceae, Hypocreales, Ascomycota) and related genera with Cylindrocarpon-like anamorphs. Stud. Mycol. 68, 57-78. https://doi. org/10.3114/sim.2011.68.03.

Cline, E.T., Ammirati, J.F., Edmonds, R.L., 2005. Does proximity to mature trees influence ectomycorrhizal fungus communities of Douglas-fir seedlings? New Phytol. 166 (3), 993-1009.

Cloete, K.J., Valentine, A.J., Stander, M.A., Blomerus, L.M., Botha, A., 2009. Evidence of symbiosis between the soil yeast Cryptococcus laurentii and a Sclerophyllous Medicinal Shrub, Agathosma betulina (Berg.) Pillans. Microb. Ecol. 57, 624-632. https://doi.org/10.1007/s00248-008-9457-9.

Corrales, A., Turner, B.L., Tedersoo, L., Anslan, S., Dalling, J.W., 2017. Nitrogen addition alters ectomycorrhizal fungal communities and soil enzyme activities in a tropical montane forest. Fung. Ecol. 27, 14-23.

Coulin, C., Aizen, M.A., Garibaldi, L.A., 2019. Contrasting responses of plants and pollinators to woodland disturbance. Austral Ecology 1040-1051.

Davey, M.L., 2012. Seasonal trends in the biomass and structure of bryophyte- associated fungal communities explored by 454 pyrosequencing. New Phytol. 195, 844-856. https://doi.org/10.1111/j.1469-8137.2012.04215.x

De Garcia, V., Brizzio, S., van Broock, M.R., 2012. Yeasts from glacial ice of Patagonian Andes, Argentina. FEMS Microbiol. Ecol. 82 (2), 540-550. https://doi.org/10.1111/j. 1574-6941.2012.01470.x.

Diehl, P., Mazzarino, M.J., Funes, F., Fontenla, S., Gobbi, M., Ferrari, J., 2003. Nutrient conservation strategies in native Andean-Patagonian forests. J. Veg. Sci. 14 (1), 63-70.

Diehl, P., Mazzarino, M.J., Fontenla, S., 2008. Plant limiting nutrients in AndeanPatagonian woody species: effects of interannual rainfall variation, soil fertility and mycorrhizal infection. For. Ecol. Manage. 255 (7), 2973-2980. https://doi.org/10. 1016/j.foreco.2008.02.003.

Donoso, C., Lara, A., 1995. Utilización de los bosques nativos en Chile: pasado, presente y futuro. In: Armesto, J.J., Villagrán, C., Arroyo, M.K. (Eds.) Ecología de los bosques nativos. Editorial Universitaria, Santiago de Chile. pp. 363-388.

Dube, F., Zagal, E., Stolpe, N., Espinosa, M., 2009. The influence of land-use change on the organic carbon distribution and microbial respiration in a volcanic soil of the Chilean Patagonia. For. Ecol. Manage. 257 (8), 1695-1704. https://doi.org/10.1016/ j.foreco.2009.01.044.

Dumbrell, A.J., Ashton, P.D., Aziz, N., Feng, G., Nelson, M., Dytham, C., Fitter, A.H., Helgason, T., 2011. Distinct seasonal assemblages of arbuscular mycorrhizal fung revealed by massively parallel pyrosequencing. New Phytol. 190 (3), 794-804. https://doi.org/10.1111/j.1469-8137.2010.03636.x.

Duo Saito, R.A., Connell, L., Rodriguez, R., Redman, R., Libkind, D., de Garcia, V., 2018. Metabarcoding analysis of the fungal biodiversity associated with Castaño Overa Glacier - Mount Tronador, Patagonia, Argentina. Fung. Ecol. 36, 8-16. https://doi. org/10.1016/j.funeco.2018.07.006.

Edgar, R.C., 2004. MUSCLE: multiple sequence alignment with high accuracy and high throughput. Nucl. Acids Res. 32 (5), 1792-1797. https://doi.org/10.1093/nar/ gkh340.

Erlandson, S.R., Savage, J.A., Cavender-Bares, J.M., Peay, K.G., 2016. Soil moisture and chemistry influence diversity of ectomycorrhizal fungal communities associating with willow along an hydrologic gradient. FEMS Microbiol. Ecol. 92 (1), fiv148.

Fernández, N., Messuti, M.I., Fontenla, S., 2012. Co-occurrence of arbuscular mycorrhizas and dark septate endophytes in terrestrial ferns from a rainforest in Patagonia, Argentina. Journal of Basic Microbiology 52: 1-11. IF: 1.266.ISI: 2011: 90/114 (Microbiology). Online ISSN: 1521-4028.

Fernández, N.V., Fontenla, S.B., Moguilevsky, D., Meie, S., Rilling, J., Cornejo, P., 2018. Nothofagus pumilio forest affected by recent tephra deposition in northern Patagonia. II- Shifts in diversity and structure of rhizosphere fungal communities. J. Soil Sci. Plant Nutr. 18 (2), 499-511.

Fernández, N.V., Mestre, M.C., Marchelli, P., Fontenla, S.B., 2012b. Yeast and yeast-like fungi associated with dry indehiscent fruits of Nothofagus nervosa in Patagonia, Argentina. FEMS Microbiol. Ecol. 80 (1), 179-192. https://doi.org/10.1111/j.1574. 6941.2011.01287.x.

Fontenla, S., Godoy, R., Rosso, P., Havrylenko, M., 1998. Root associations in Austrocedrus forests and seasonal dynamics of arbuscular mycorrhizas. Mycorrhiza 8 (1), 29-33.

Fontenla, S., Puntieri, J., Ocampo, J.A., 2001. Mycorrhizal associations in the Patagonia steppe, Argentina. Plant Soil 233 (13-29), 2001.

Gardes, M., Bruns, T.D., 1996. Community structure of ectomycorrhizal fungi in a Pinus muricata forest: above-and below-ground views. Can. J. Bot. 74, 1572-1583.

Godoy, R., Marín, C., 2019. Chapter 16: Mycorrhizal Studies in Temperate Rainforests of Southern Chile. In: Pagano, M.C., Lugo, M.A. (Eds.) Mycorrhizal Fungi in South America. Springer Editorial, New York, pp. 315-341.

Goldmann, K., Schöning, I., Buscot, F., Wubet, T., 2015. Forest management type influences diversity and community composition of soil fungi across temperate forest ecosystems. Front. Microbiol. 6, 1-11. https://doi.org/10.3389/fmicb.2015.01300.

Gowda, J.H., Kitzberger, T., Suárez, L., 2014. Comunidades vegetales y ecosistemas terrestres. Informe final. Parque nacional Nahuel Huapi, Bariloche, Río Negro, Argentina.

Grosfeld, J., Chauchard, L., Gowda, J.H., 2019. Debates: ¿Podemos manejar sustentablemente el bosque nativo de Patagonia Norte? Ecol. Austral. 29, 156-163.

Grossart, H.P., Wurzbacher, C., James, T.Y., Kagami, M., 2016. Discovery of dark matter fungi in aquatic ecosystems demands a reappraisal of the phylogeny and ecology of zoosporic fungi. Fung. Ecol. 19, 28-38. https://doi.org/10.1016/j.funeco.2015.06. 004.

Grossberg, S.P., 2009. Forest Management. Nova Science Publishers, Inc., Nueva York, pp. 329.

Halbwachs, H., Karasch, P., Gw, G., 2013. The diverse habitats of Hygrocybe - peeking into an enigmatic lifestyle. Mycosphere 4 (4), 773-792. https://doi.org/10.5943/ mycosphere/4/4/14.

Hawksworth, D.L., Lücking, R., 2017. Fungal Diversity Revisited: 2.2 to 3.8 Million Species. Microbiol. Spectrum 5 (4), 1-17. https://doi.org/10.1128/microbiolspec. FUNK-0052-2016.

Henrik Nilsson, R., Tedersoo, L., Lindahl, B.D., et al., 2011. Towards standardization of the description and publication of next-generation sequencing datasets of fungal communities. New Phytol. 191 (2), 314-318. https://doi.org/10.1111/j.1469-8137. 2011.03755.x.

Hewitt, R.E., Taylor, D.L., Hollingsworth, T.N., Anderson, C.B., Pastur, G.M., 2018. Variable retention harvesting influences belowground plant-fungal interactions of Nothofagus pumilio seedlings in forests of southern Patagonia. PeerJ 2018 (7), 1-25. https://doi.org/10.7717/peerj.5008.

Higman, S., Bass, S., Judd, N., Mayers, J., Nussbaum., R., 2000. The sustainable forestry handbook. A practical guide fortropical forest managers on implementing new standards Earthscan Pub. Londres. 289 p.

Jones, M.D., Durall, D.M., Cairney, J.W., 2003. Ectomycorrhizal fungal communities in young forest stands regenerating after clearcut logging. New Phytol. 157 (3), 399-422.

Jones, M.D., Hagerman, S.M., Gillespie, M., 2002. Ectomycorrhizal colonization and richness of previously colonized, containerized Picea engelmannii does not vary across clearcuts when planted in mechanically site-prepared mounds. Can. J. For. Res. 32 (8), 1425-1433.

Kauserud, H., Heegaard, E., Halvorsen, R., Boddy, L., Høiland, K., Stenseth, N.C., 2011. Mushroom's spore size and time of fruiting are strongly related: is moisture important? Biol. Lett. 7 (2), 273-276. https://doi.org/10.1098/rsbl.2010.0820. 
Kitzberger, T., Veblen, T.T., 1999. Fire-induced changes in northern Patagonian landscapes. Landscape Ecol. 14 (1), 1-15.

Klein, D., Fuentes, J.P., Schmidt, A., Schmidt, H., Schulte, A., 2008. Soil organic C as affected by silvicultural and exploitative interventions in Nothofagus pumilio forests of the Chilean Patagonia. For. Ecol. Manage. 255 (10), 3549-3555. https://doi.org/ 10.1016/j.foreco.2008.03.002.

Kuos, S., 1996. Chapter 32: Phosphorus. In: Methods of Soil Analysis. Part 3. Chemical Methods. In: Bigham, J.M., Bartels, J.M. (Eds.). Soil Science Society of America, Inc.: Madison, WI, pp. 869-919.

La Manna, L., Barroetaveña, C., 2011. Propiedades químicas del suelo en bosques de Nothofagus antarctica y Austrocedrus chilensis afectados por fuego. Revista de la Facultad de Ciencias Agrarias 43 (1), 41-55.

Laclau, P., 1997. Los ecosistemas forestales y el hombre en el sur de Chile y Argentina. Fundación Vida Silvestre Argentina. Boletín Técnico 8, 34.

Larreta, P., Martín-López, B., Mastrangelo, M., Garibaldi, L., 2017. Servicios Ecosistémicos en Latinoamérica. De la investigación a la acción. Ecol. Austral., 27, 094-098. 10.25260/EA.17.27.1.1.611.

Lauber, C.L., Strickland, M.S., Bradford, M.A., Fierer, N., 2008. The influence of soil properties on the structure of bacterial and fungal communities across land-use types. Soil Biol. Biochem. 40 (9), 2407-2415. https://doi.org/10.1016/j.soilbio.2008.05. 021.

Libkind Frati, D., 2006. Levaduras carotenogénicas de ambientes acuáticos de la Patagonia noroccidental argentina. Aplicaciones biotecnológicas. $\mathrm{PhD}$ thesis. Universidad Nacional de, Tucumán, Argentina.

Lim, Y.W., Kim, B.K., Kim, C., Jung, H.S., Kim, B.S., Lee, J.H., Chun, J., 2010. Assessment of soil fungal communities using pyrosequencing. J. Microbiol. 48 (3), 284-289. https://doi.org/10.1007/s12275-010-9369-5.

Lindahl, B.D., Nilsson, R.H., Tedersoo, L., et al., 2013. Fungal community analysis by high-throughput sequencing of amplified markers-a user's guide. New Phytol. 199 (1), 288-299. https://doi.org/10.1111/nph.12243.

Lodge, D.J., Padamsee, M., Matheny, P.B., et al., 2014. Molecular phylogeny, morphology, pigment chemistry and ecology in Hygrophoraceae (Agaricales). Fungal Divers. 64, 1-99. https://doi.org/10.1007/s13225-013-0259-0.

Malmsheimer, R.W., Heffernan, P., Brink, S., et al., 2008. Forest management solutions for mitigating climate change in the United States. J. Forest. 106 (3), 115-173.

Mandyam, K., Jumpponen, A., 2005. Seeking the elusive function of the root-colonising dark septate endophytic fungi. Stud. Mycol. 53 (1), 173-189. https://doi.org/10. 3114/sim.53.1.173.

Marín, C., Godoy, R., Valenzuela, E., Schloter, M., Wubet, T., Boy, J., Gschwendtner, S., 2017. Functional land-use change effects on soil fungal communities in Chilean temperate rainforests. J. Soil Sci. Plant Nutr. 17 (4), 985-1002. https://doi.org/10. 4067/S0718-95162017000400011.

McDowell, R.W., Stewart, I., 2006. The phosphorus composition of contrasting soils in pastoral, native and forest management in Otago, New Zealand: Sequential extraction and 31P NMR. Geoderma 130, 176-189. https://doi.org/10.1016/j.geoderma.2005. 01.020 .

Mestre, M.C., Fontenla, S., Bruzone, M.C., Fernández, N.V., Dames, J., 2016. Detection of plant growth enhancing features in psychrotolerant yeasts from Patagonia (Argentina). J. Basic Microbiol. 56 (10), 1098-1106. https://doi.org/10.1002/jobm. 201500728.

Mestre, M.C., Fontenla, S., Rosa, C.A., 2014. Ecology of cultivable yeasts in pristine forests in northern Patagonia (Argentina) influenced by different environmental factors. Can. J. Microbiol. 60 (6), 371-382. https://doi.org/10.1139/cjm-2013-0897.

Miyamoto, Y., Sakai, A., Hattori, M., Nara, K., 2015. Strong effect of climate on ectomycorrhizal fungal composition: evidence from range overlap between two mountains. ISME J. 9 (8), 1870-1879.

Nelson, D.W., Sommers, L.E., 1996. Chapter 34: Total carbon, organic carbon and organic matter. In: Bigham, J.M., Bartels, J.M. (Eds.) Methods of Soil Analysis. Part 3. Chemical Methods. Soil Science Society of America, Inc.: Madison, WI. pp. 961-1010.

Nguyen, N.H., Song, Z., Bates, S.T., Branco, S., Tedersoo, L., Menke, J., Schilling, J.S., Kennedy, P.G., 2016. FUNGuild: An open annotation tool for parsing fungal community datasets by ecological guild. Fung. Ecol. 20, 241-248. https://doi.org/10. 1016/j.funeco.2015.06.006.

Oksanen, J., Blanchet, F.G., Friendly, M., Kindt, R., Legendre, P., McGlinn, D., Minchin, P. R., O'Hara, R.B., Simpson, G.L., Solymos, P., Stevens, M.H.H., Szoecs E., Wagner, H., 2019. Vegan: Community Ecology Package. R package version 2.5-6. < https:// CRAN.R-project.org/package $=$ vegan $>$

Oulas, A., Pavloudi, C., Polymenakou, P., Pavlopoulos, G.A., Papanikolaou, N., Kotoulas, G., Arvanitidis, C., Iliopoulos, I., 2015. Metagenomics: Tools and insights for analyzing next-generation sequencing data derived from biodiversity studies. Bioinf. Biol. Insights 9, 75-88. https://doi.org/10.4137/BBI.S12462.

Pagano, M.C., Lugo, M.A. (Eds.), 2019. Mycorrhizal Fungi in South America. Springer International Publishing.

Peay, K.G., Russo, S.E., McGuire, K.L., Lim, Z., Chan, J.P., Tan, S., Davies, S.J., 2015. Lack of host specificity leads to independent assortment of dipterocarps and ectomycorrhizal fungi across a soil fertility gradient. Ecol. Lett. 18 (8), 807-816.

Peri, P.L., Hansen, N., Rusch, V., Tejera, L., Monelos, L., Fertig, M., Bahamonde, H.y., Sarasola, M., 2005. Pautas de manejo de sistemas silvopastoriles en bosques nativos de Nothofagus antarctica (ñire) en Patagonia. In: Actas del Primer Congreso Nacional de Sistemas Silvopastoriles, Misiones, Argentina, pp. 151-155.

Pinheiro, J., Bates, D., DebRoy, S., Sarkar, D., R Core Team, 2019. nlme: Linear and Nonlinear Mixed Effects Models. R package version 3.1-140, < https://CRAN.Rproject.org $/$ package $=$ nlme $>$.

Purahong, W., Kapturska, D., Pecyna, M.J., Jariyavidyanont, K., Kaunzner, J., Juncheed, K., Uengwetwanit, T., Rudloff, R., Schulz, E., Hofrichter, M., Schloter, M., Krüger, D., Buscot, F., 2015. Effects of Forest Management Practices in Temperate Beech Forests on bacterial and fungal communities involved in leaf litter degradation. Microb. Ecol. 69 (4), 905-913. https://doi.org/10.1007/s00248-015-0585-8.

R Core Team, 2019. R: A language and environment for statistical computing. $\mathrm{R}$ Foundation for Statistical Computing, Vienna, Austria. URL: < https://www.Rproject.org/ >

Raaijmakers, J.M., Paulitz, T.C., Steinberg, C., Alabouvette, C., Moënne-Loccoz, Y., 2009. The rhizosphere: a playground and battlefield for soilborne pathogens and beneficial microorganisms. Plant Soil 321 (1-2), 341-361.

Read, D.J., Perez-Moreno, J., 2003. Mycorrhizas and nutrient cycling in ecosystems - a journey towards relevance? New Phytol. 157 (1), 475-492. https://doi.org/10.1046/ j.1469-8137.2003.00704.x.

Redel, Y., Rubio, R., Godoy, R., Borie, F., 2008. Phosphorus fractions and phosphatase activity in an Andisol under different forest ecosystems. Geoderma 145, 216-221. https://doi.org/10.1016/j.geoderma.2008.03.007.

Redel, Y.D., Escudey, M., Alvear, M., Conrad, J., Borie, F., 2015. Effects of land use change on p bioavailability determined by chemical fractionation and 31P-NMR spectroscopy in a nothofagus forest and adjacent grassland. J. Soil Sci. Plant Nutr. 15 (4), 1061-1070. https://doi.org/10.4067/S0718-95162015005000074.

Reque, J.A., Sarasola, M., Gyenge, J., Fernández, M.E., 2007. Caracterización silvícola de ñirantales del norte de la Patagonia para la gestión forestal sostenible. Bosque 28 (1), 33-45. https://doi.org/10.4067/S0717-92002007000100006.

Rinaldi, A.C., Comandini, O., Kuyper, T.W., 2008. Ectomycorrhizal fungal diversity: seperating the wheat from the chaff. Fungal Divers. 33, 1-45.

Rusch, V.E., Rusch, G.M., Goijman, A.P., Varela, S., Claps, L., 2017. Ecosystem services to support environmental and socially sustainable decision-making. Ecol. Austral. 27, 162-176.

Satti, P., Mazzarino, M.J., Roselli, L., Crego, P., 2007. Factors affecting soil P dynamics in temperate volcanic soils of southern Argentina. Geoderma 139 (1-2), 229-240. https://doi.org/10.1016/j.geoderma.2007.02.005.

SAyDS, 2007. Primer Inventario Nacional de Bosques Nativos. Informe regional Bosques Andino Patagónicos. Buenos Aires, pp. 1-104.

Schoch, C.L., Seifert, K.A., Huhndorf, S., et al., 2012. Nuclear ribosomal internal transcribed spacer (ITS) region as a universal DNA barcode marker for Fungi. Proc. Natl. Acad. Sci. 109 (16), 6241-6246. https://doi.org/10.1073/pnas.1117018109.

Seitzman, B.H., Ouimette, A., Mixon, R.L., Hobbie, E.A., Hibbett, D.S., 2011. Conservation of biotrophy in Hygrophoraceae inferred from combined stable isotope and phylogenetic analyses. Mycologia 103 (2), 280-290. https://doi.org/10.3852/10-195.

Sterkenburg, E., Bahr, A., Durling, M.B., Clemmensen, K.E., Lindahl, B.D., 2015. Changes in fungal communities along a boreal forest soil fertility gradient. New Phytol. 207, 1145-1158. https://doi.org/10.1111/nph.13426.

Stockinger, H., Krüger, M., Schüßler, A., 2010. DNA barcoding of arbuscular mycorrhizal fungi. New Phytol. 187, 461-474. https://doi.org/10.1111/j.1469-8137.2010. 03262.x.

Suarez, D.L., 1996. Chapter 20: Beryllium, Magnesium, Calcium, Strontium, and Barium. In: Methods of Soil Analysis. Part 3. Chemical Methods. In: Bigham, J.M., Bartels, J.M (Eds.). Soil Science Society of America, Inc.: Madison, WI. pp. 575-601.

Tacón Clavaín, A., 2004. Manual de productos forestales no madereros. Programa de fomento para la conservación de tierras privadas de la Décima Región. Valdivia, Chile. CIPMA. 22.

Talbot, J.M., Bruns, T.D., Smith, D.P., et al., 2013. Independent roles of ectomycorrhizal and saprotrophic communities in soil organic matter decomposition. Soil Biol. Biochem. 57, 282-291.

Taylor, A.F.S., Martin, F., Read, D.J., 2000. Fungal diversity in ectomycorrhizal communities of Norway spruce [Picea abies (L.) Karst.] and beech (Fagus sylvatica L.) along north-south transects in Europe. In Carbon and nitrogen cycling in European forest ecosystems. Springer, Berlin, Heidelberg, pp. 343-365.

Taylor, D.L., Hollingsworth, T.N., McFarland, J.W., Lennon, N.J., Nusbaum, C., Ruess, R.W., 2014. A first comprehensive census of fungi in soil reveals both hyperdiversity and fine-scale niche partitioning. Ecol. Monogr. 84 (1), 3-20. https://doi.org/10. 1890/12-1693.1.

Taylor, D.L., Sinsabaugh, R.L. 2015. Chapter 5: The Soil Fungi: Occurrence, Phylogeny, and Ecology. In: Soil microbiology, ecology and biochemistry. Paul, E.A. (Eds.) Fourth edition. Elsevier Inc. pp. 77-109.

Tedersoo, L., Bahram, M., Polme, S., et al., 2014. Global diversity and geography of soil fungi. Science 346 (6213), 1256688. https://doi.org/10.1126/science.1256688.

Tedersoo, L., Mett, M., Ishida, T.A., Bahram, M., 2013. Phylogenetic relationships among host plants explain differences in fungal species richness and community composition in ectomycorrhizal symbiosis. New Phytol. 199 (3), 822-831.

Tedersoo, L., Nilsson, R.H., Abarenkov, K., et al., 2010. 454 Pyrosequencing and Sanger sequencing of tropical mycorrhizal fungi provide similar results but reveal substantial methodological biases. New Phytol. 188 (1), 291-301. https://doi.org/10.1111/j. 1469-8137.2010.03373.x.

Tello, S.A., Silva-flores, P., Agerer, R., Halbwachs, H., Beck, A., Persoh, D., 2013. Hygrocybe virginea is a systemic endophyte of Plantago lanceolata. Mycol. Prog. 13 (3), 471-475. https://doi.org/10.1007/s11557-013-0928-0.

Truong, C., Gabbarini, L.A., Corrales, A., Mujic, A.B., Escobar, J.M., Moretto, A., Smith, M.E., 2019. Ectomycorrhizal fungi and soil enzymes exhibit contrasting patterns along elevation gradients in southern Patagonia. New Phytol. 222 (4), 1936-1950. https://doi.org/10.1111/nph.15714.

Truong, C., Mujic, A.B., Healy, R., et al., 2017. How to know the fungi: combining field inventories and DNA-barcoding to document fungal diversity. New Phytol. 214 (3), 913-919. https://doi.org/10.1111/nph.14509.

Van Der Heijden, M.G.A., Bardgett, R.D., Van Straalen, N.M., 2008. The unseen majority: Soil microbes as drivers of plant diversity and productivity in terrestrial ecosystems. Ecol. Lett. 11 (3), 296-310. https://doi.org/10.1111/j.1461-0248.2007.01139.x.

Van Der Heijden, M.G.A., Klironomos, J.N., Ursic, M., et al., 1998. Mycorrhizal fungal 
diversity determines plant biodiversity, ecosystem variability and productivity. Nature 396 (6706), 69-72. https://doi.org/10.1038/23932.

Van Der Heijden, M.G.A., Martin, F.M., Selosse, M.A., Sanders, I.R., 2015. Mycorrhizal ecology and evolution: the past, the present, and the future. New Phytol. 205 (4), 1406-1423.

Vavrek, M.J., 2011. Fossil: palaeoecological and palaeogeographical analysis tools. Palaeontol. Electronica 14, 1T. http://palaeo-electronica.org/2011_1/238/index. html.

Veblen, T.T., Mermoz, M., Martin, C., Kitzberger, T., 1992. Ecological impacts of introduced animals in Nahuel Huapi Naotional Park, Argentina. Conserv. Biol. 6, 71-83. https://doi.org/10.1046/j.1523-1739.1992.610071.x.

Velázquez, M.S., Stürmer, S.L., Bruzone, C., Fontenla, S., Barrera, M., Cabello, M., 2016. Occurrence of arbuscular mycorrhizal fungi in high altitude sites of the Patagonian Altoandina region in Nahuel Huapi National Park (Argentina). Acta Botan. Brasil. 30 (4), 521-531.

Voriskova, J., Brabcová, V., Cajthaml, T., Baldrian, P., 2014. Seasonal dynamics of fungal communities in a temperate oak forest soil. New Phytol. 201 (1), 269-278. https:// doi.org/10.1111/nph.12481.
Wang, Q., Garrity, G.M., Tiedje, J.M., Cole, J.R., 2007. Naive Bayesian Classifier for Rapid Assignment of rRNA sequences into the new bacterial taxonomy. Appl. Environ. Microbiol. 73 (16), 5261-5267. https://doi.org/10.1128/AEM.00062-07.

White, N., Chilvers, G., Evans, G., 1962. Antifungal activity of Cylindrocarpon radicicola Wr. Nature 195, 406-407.

White, T.J., Bruns, T., Lee, S.J.W.T., Taylor, J.L., 1990. Amplification and direct sequencing of fungal ribosomal RNA genes for phylogenetics. In: Innis, M.A. (Ed.), PCR Protocols: A Guide to Methods and Applications. Academic Press, San Diego, CA, pp. 315-322.

Zhang, T., Wang, N.F., Liu, H.Y., Zhang, Y.Q., Yu, L.Y., 2016. Soil pH is a Key Determinant of Soil Fungal Community Composition in the Ny-Ålesund Region, Svalbard (High Arctic). Front. Microbiol. 7, 227. https://doi.org/10.3389/fmicb.2016.00227.

Zinger, L., Coissac, E., Choler, P., Geremia, R.A., 2009. Assessment of microbial communities by graph partitioning in a study of soil fungi in two alpine meadows. Appl. Environ. Microbiol. 75 (18), 5863-5870. https://doi.org/10.1128/AEM.00748-09.

Zuur, A., Ieno, E.N., Walker, N., Saveliev, A.A., Smith, G.M., 2009. Mixed effects models and extensions in ecology with. R. Springer Science \& Business Media. 